\title{
Recent Progresses in Eco-Friendly Fabrication and Applications of Sustainable Aerogels from Various Waste Materials
}

\author{
Phuc T. T. Nguyen ${ }^{1} \cdot$ Nga H. N. Do ${ }^{4,5} \cdot$ Xue Yang Goh ${ }^{1} \cdot$ Chong Jin Goh ${ }^{1} \cdot$ Ren Hong Ong ${ }^{1}$ Phung K. Le ${ }^{4,5}$. \\ Nhan Phan-Thien ${ }^{1} \cdot$ Hai M. Duong ${ }^{1,2,3}[$
}

Received: 28 June 2021 / Accepted: 24 October 2021 / Published online: 2 November 2021

(C) The Author(s), under exclusive licence to Springer Nature B.V. 2021

\begin{abstract}
Tons of waste from residential, commercial and manufacturing activities are generated due to the growing population, urbanization and economic development, prompting the need for sustainable measures. Numerous ways of converting waste to aerogels, a novel class of ultra-light and ultra-porous materials, have been researched to tackle the issues of waste. This review provides an overview of the status of aerogels made from agricultural waste, municipal solid, and industrial waste focusing on the fabrication, properties, and applications of such aerogels. The review first introduced common methods to synthesize the aerogels from waste, including dispersion and drying techniques. Following that, numerous works related to aerogels from waste are summarized and compared, mainly focusing on the sustainability aspect of the processes involved and their contributions for environmental applications such as thermal insulation and oil absorption. Next, advantages, and disadvantages of the current approaches are analyzed. Finally, some prospective waste aerogels and its applications are proposed.
\end{abstract}

\section{Graphic Abstract}
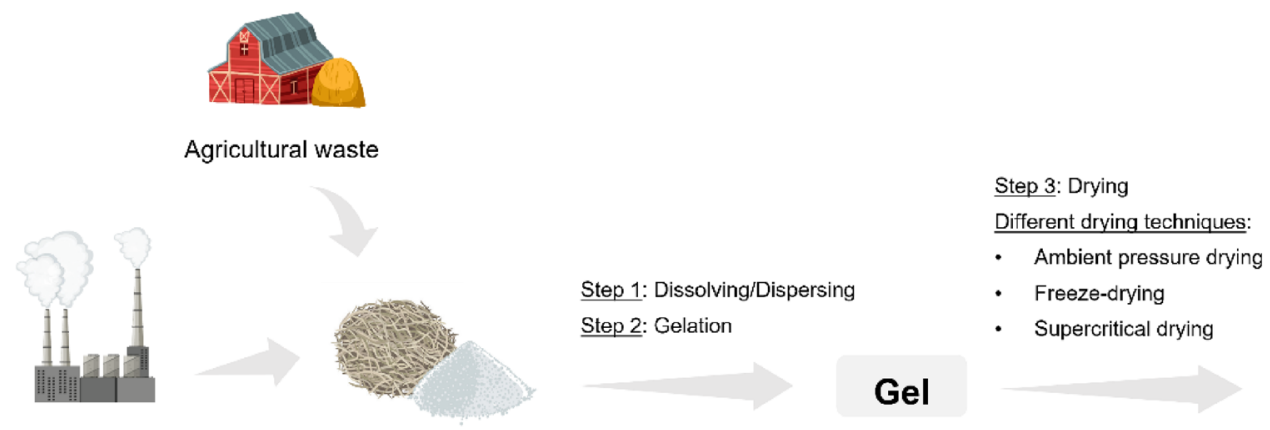

Industrial waste

Precursor

Aerogels

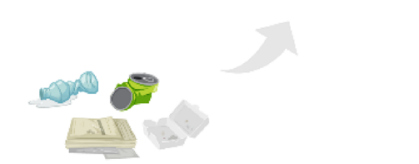

Municipal solid waste

\begin{tabular}{ll}
\multicolumn{2}{c}{ Applications } \\
Thermal insulation & Bioelectronics \\
Oil sorption & Filtration \\
Energy storage & Water treatment \\
Catalyst support & $\ldots$
\end{tabular}

Keywords Aerogels $\cdot$ Municipal solid waste $\cdot$ Industrial waste $\cdot$ Agricultural waste $\cdot$ Recycle

Hai M. Duong

mpedhm@nus.edu.sg

Extended author information available on the last page of the article 


\section{Statement of Novelty}

This review is undertaken to summarize, compare and evaluate several approaches to utilize different types of waste for the preparation of aerogels in terms of sustainability and engineering applications. Compared to previous works, this review focuses on the status and environmental impacts of wastes, and efforts from researchers worldwide to convert these wastes into aerogels for diverse applications through ecofriendly methods. Environmental aspects including impacts of synthesis procedures and solutions for environmental problems such as heat insulation and oil spill cleaning are highlighted. Our perspectives on the advantages and disadvantages of the mentioned approaches are presented in detail. Furthermore, we propose the prospects of the development of aerogels from waste as suggestions for future works. Hopefully, this review can inspire more studies to create high value materials from waste by ecofriendly fabrication methods to partly combat the increasing waste generation and offer solutions for engineering problems.

\section{Introduction}

Driven by a rapid growing population, urbanization and economic development, waste generation is significantly increasing all over the world. Primary waste sources include residential households, municipal services, treatment plants, and industrial and agricultural processes [1]. Municipal solid waste refers to waste generated in a community from households, offices, restaurants, schools, and other institutions. According to a report of the World Bank Group in 2018 [2], approximately $0.74 \mathrm{~kg}$ of municipal solid waste is produced per capita per day. This figure varies widely by country, ranging from 0.11 to $4.54 \mathrm{~kg}$ per capita per day. Waste generation is related to income levels. Despite only accounting for $16 \%$ of the world's population, high-income nations produce around 34 percent, or 683 million tons annually, of the world's waste. The global municipal solid waste is around 2.01 billion tons in 2016 and is projected to reach 3.40 billion tons by 2050 .

However, municipal solid waste is only one of the waste sources that the world is facing. Figure 1 shows the amount of waste generated per capita per day worldwide by source. Industrial waste generation is much higher than that of municipal solid waste, of approximately 17.2 times higher. Statistics show that the industrial waste generation grows significantly with increase in income level. In high-income nations, the average amount of industrial waste is $42.62 \mathrm{~kg} /$ capita/day, while this figure is only $0.36 \mathrm{~kg} / \mathrm{capita} / \mathrm{day}$ in lower-middle income nations [2]. Therefore, a rapid industrialization seen in recent decades can exacerbate environmental problems without a proper waste management strategy. The number for agricultural waste generation is $3.35 \mathrm{~kg} /$ capita/day and can be higher in large agricultural producing countries. Construction and demolition waste accounts for $1.68 \mathrm{~kg} / \mathrm{capita} /$ day, mainly emerged from demolition and rehabilitation of existing sites [3]. Although only making up a small fraction, hazardous, medical and electronic waste (e-waste) can severely damage the environment and human health if disposed improperly. Especially, the generation of e-waste is significantly increasing with the rapid development of technology that accompanies with modern urbanization.

Due to the negative impacts of waste on the environment and community health, governments have put forth many efforts into waste management. Solid waste management
Fig. 1 Global average waste generation by source [2]

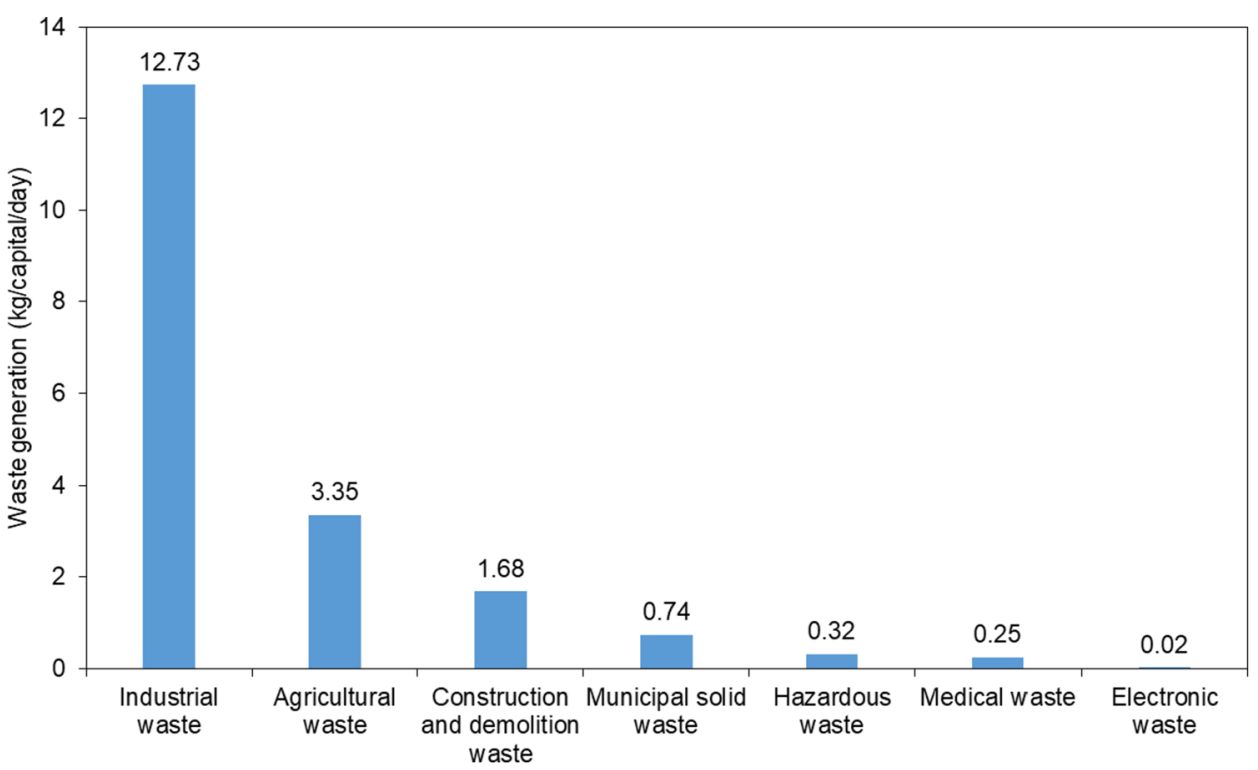


accounts for more than $10 \%$ of municipal budgets in middle-income countries, and 4\% in high-income countries [2]. According to the waste management hierarchy, waste should be managed in accordance with the following order of preference: prevention, reuse, recycling, treatment and disposal [4]. Despite not being the first priority, recycling offers numerous benefits such as saving energy, conserving natural resources, protecting the environment, and reducing waste amount to landfills and incinerators. Recycling is integral in converting a linear economy into circular economy to meet the sustainable development goals. Items such as papers, plastics, food, glass, metals, textiles and tires are recyclable. In 2019, Singapore recycled $99 \%$ of metal, $98 \%$ of slag and $94 \%$ of tires [5]. Moreover, waste can be recycled to high value materials such as activated carbon [6], graphene [7], building materials [8], membrane [9], and metals [10], adding more economic values.

Aerogels, a class of ultra-porous solid materials, are wellknown for their low density $\left(0.0011-0.5 \mathrm{~g} / \mathrm{cm}^{3}\right)$, high porosity $(90-99 \%)$ and large surface area $\left(10-2000 \mathrm{~m}^{2} / \mathrm{g}\right)[11]$. The first aerogels were reported by Kistler in 1931 and followed by various aerogels from different precursors such as silica, cellulose, and organic compounds. The most commercially popular aerogels are silica aerogels, mainly used for thermal insulation. However, the main restriction of the wide use of aerogels is their high cost. One $\mathrm{m}^{2}$ of a commercial aerogel for thermal insulation with a thermal conductivity of $15 \mathrm{~mW} / \mathrm{mK}$ costs 280 USD, while it costs only 15 USD per $\mathrm{m}^{2}$ for a conventional insulator with a thermal conductivity of $32 \mathrm{~mW} / \mathrm{mK}$ and the same overall heat transfer coefficient [12]. A monolithic cylinder carbon aerogel for catalyst support with the size of $1 \mathrm{~cm} \times 0.4 \mathrm{~cm}$ (diameter $\times$ height) costs 80 USD [13], while the same amount of silica gel with the same surface area costs approximately 3 USD [14]. One reason for this high cost is expensive starting materials, which limits the diversity of commercial aerogels. To obtain silica aerogels via supercritical drying, the precursor costs $95.4 \%$ and $42 \%$ of the production cost, when tetramethyl orthosilicate and sodium silicate are used, respectively. For carbon aerogels, the organic precursors cost makes up from $63 \%$ (phenolic-furfural) to $80 \%$ (resorcinol-formaldehyde) of the production cost [15]. Therefore, it is necessary to find lowcost precursors to reduce the cost of aerogel production.
Inspired by recycling, many approaches to aerogels from waste have been reported. These are advanced solutions for reducing the cost of starting materials and the amount of waste to landfills and incinerators. Researchers have mainly utilized municipal solid, agricultural and industrial wastes as precursors of aerogels due to their abundance. Many novel applications of aerogels besides thermal insulation have been discovered such as personal care products, medical devices, oil and organic solvents sorption, filtration, sound insulation, energy absorption, energy storage, bioelectronics, water treatment and catalyst, offering sustainable solutions for environmental and energy problems. Previous reviews mainly focused on a specific types of aerogel such as silica aerogel [16], cellulose aerogel [17], and carbon aerogel, [18] or on certain application such as acoustic insulation [19], photocatalyst [20] and biomedical applications [21]. However, taking advantage of wastes such as municipal solids, agricultural and industrial by-products to create high-value engineering aerogels has been a general trend in the world. This review will focus on analyzing the outstanding properties and applications of recycled aerogels from different wastes.

\section{Fabrication of Aerogels from Waste}

Common preparation methods of aerogels from waste are illustrated in Fig. 2. Generally, the fabrication of aerogels from waste is similar to that of conventional aerogels. The most well-known method for the synthesis of aerogels is sol-gel process, in which the precursor forms a colloid by hydrolysis and condensation reactions, and then turns into a gel by the formation of crosslinks. The resulting gel can be aged to strengthen the crosslinked network, and then solvents are replaced by air to obtain the aerogels. This is the approach using by Kistler et al. [22] for the synthesis of the first aerogel. In this work, the silicate precursor was hydrolyzed and condensed in an acidic condition. Since the evaporation of water would cause cracks and shrinkage to the gel due to the capillary force, solvent exchange was carried out to replace water by solvents with low critical point such as alcohol and propane. These solvents were then removed by drying over their critical point to avoid the liquid-vapor

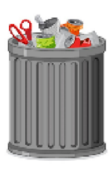

Waste

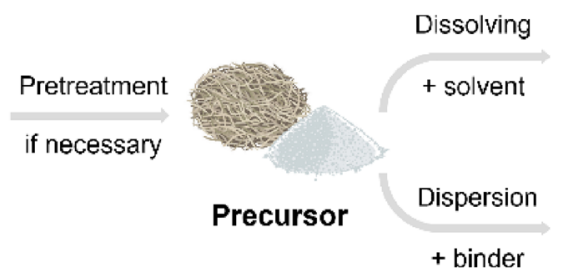

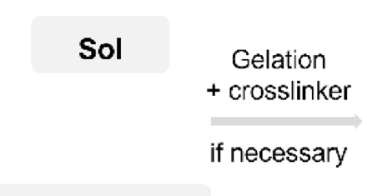

Suspension

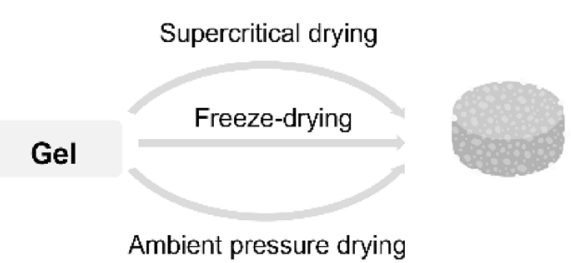

Fig. 2 Schematic diagram of fabrication of aerogels using waste as raw materials 
interface and achieve the aerogel with a reserved polymer network.

Gradually, more advanced gel drying techniques are introduced to modify the direct supercritical drying of Kistler, including supercritical $\mathrm{CO}_{2}\left(\mathrm{scCO}_{2}\right)$ drying, ambient pressure drying, and freeze-drying. The $\mathrm{scCO}_{2}$ drying utilize the high solubility of $\mathrm{scCO}_{2}$ to extract the solvent with no liquid-vapor interface, reserving the highly porous and textural structure of the liquid gel. One significant advantage of $\mathrm{ScCO}_{2}$ is its low-temperature critical points $(304 \mathrm{~K}, 7.4$ $\mathrm{MPa})$ compared to other solvents such as ethanol $(517 \mathrm{~K}$, $6.4 \mathrm{MPa}$ ) and hexane (507 K, $3.03 \mathrm{MPa}$ ), thus the $\mathrm{scCO}_{2}$ is less energy-intensive [23]. In the ambient pressure drying, the surface of silica aerogel is hydrophobically modified to eliminate terminal silanol group ( $\mathrm{Si}$ -

$\mathrm{OH})$, and the solvent is exchanged into a low-surfaceenergy solvent such as hexane to minimize the shrinkage. Ambient pressure drying allows to considerably reduce the equipment and energy cost. However, $\mathrm{scCO}_{2}$ drying and ambient pressure drying usually requires amounts of organic volatile solvents for solvent exchange steps, making these two techniques non-eco-friendly and time-consuming. This disadvantage can be avoided in the freeze-drying technique, in which the ice crystals in the frozen hydrogel are removed by sublimation at low pressure. Freeze-drying does not require solvent modifications; thus, no waste chemicals are generated. It is noted that generally the resultant gels that forms out of ambient pressure drying is termed xerogels while gels that are formed out of freeze-drying is termed cryogels [24]. However, in this review, the term aerogel will be used throughout as an indication to the porous material obtained from each of the gel drying method.

Compared to pure aerogel precursors, the composition of waste is complex and varied by sources. For example, cellulose from leaves and trees are usually found within a lignin shell, while cellulose from paper waste can be impure by sizing materials, fillers and pigments. The composition of the cellulose fibers in a specific species, such as pineapple, also depends on the maturity, the location and the fibers extraction conditions [25]. Therefore, pretreatment such as washing, grinding or thermal treating is usually conducted to remove the impurities and extract the desired components. Organic waste can be calcinated to serve as a source of carbon. Sometimes, solvent extraction is performed to obtain precursors such as sodium silicate from fly ash and rice husk ash.

After pretreatment, the precursor is dissolved into appropriate solvents to obtain a sol or dispersed with the support of binders to form a suspension. The former approach is the sol-gel process, which is mostly applicable for sodium silicate and metal powders. Polymeric materials are generally difficult to be dissolved in common solvents. For example, dissolving of cellulose requires the use of concentrated
$\mathrm{NaOH} / \mathrm{urea}$ solution or ionic liquid. In these cases, the latter approach using polymers as binders is more favorable. When dispersing solid precursors in a polymer solution, it is important to obtain a stable suspension. According to Stokes' law, the settling velocity of the particle can be calculated by:

$\omega=\frac{\left(\rho_{\mathrm{p}}-\rho_{\mathrm{f}}\right) \mathrm{gd}^{2}}{18 \mu}$,

where $\omega$ is the settling velocity; $\rho_{\mathrm{p}}, \rho_{\mathrm{f}}$ are the density of particle and fluid, respectively; $d$ is the diameter of the particle; $\mu$ is the velocity and $g$ is the gravitational acceleration. To maintain a stable dispersion, the settling velocity should be kept minimum to prevent sedimentation. This is usually done by either increasing the viscosity of the polymer solution or reducing the size of raw materials. Antisettling agents such as carboxymethyl cellulose (CMC) can be employed to facilitate this step. Subsequently, the sol or the suspension is transformed into a gel by the formation of crosslinks between polymer chains. The nature of the crosslinks can be chemical (mostly covalent bond), or physical (mostly hydrogen bond). Some hydrophilic polymers can be self-assembled to form a gel at appropriate temperature. Their self-crosslinking ability is due to the presence of hydrophilic functional groups such as hydroxyl or carboxylic acid, which form hydrogen bonds between polymer chains. To further strengthen the 3-dimension scaffold, chemical crosslinkers can be introduced, such as epichlohydrin [26] or Kymene [27] in the gelation of cellulose hydrogel.

The gel is then converted into the corresponding aerogels using the mentioned drying methods. It should be noted that supercritical drying and ambient pressure drying are accompanied by solvent exchange steps, and freeze-drying technique requires the gel to be frozen. Post-treatment such as hydrophobic coating, impregnation or carbonization can be conducted on the obtained aerogel to better serve for certain applications.

\section{Aerogels from Municipal Solid Waste}

Figure 3 describes main components of municipal solid waste, including food, green, paper, plastic, rags, metal, glass and other wastes. Food waste and green waste are dominant types of municipal solid waste, which accounts for $44 \%$ of the total. However, the utilization of food waste in advanced materials is limited due to its complex and unstable composition. In this review, various types of food waste such as coffee grounds, okara, sugarcane bagasse and banana peels are classified as agricultural waste and discussed their utilization to make aerogels in Sect. 4. Preparation, properties and applications of some aerogels from municipal solid waste are tabulated in Table 1. 


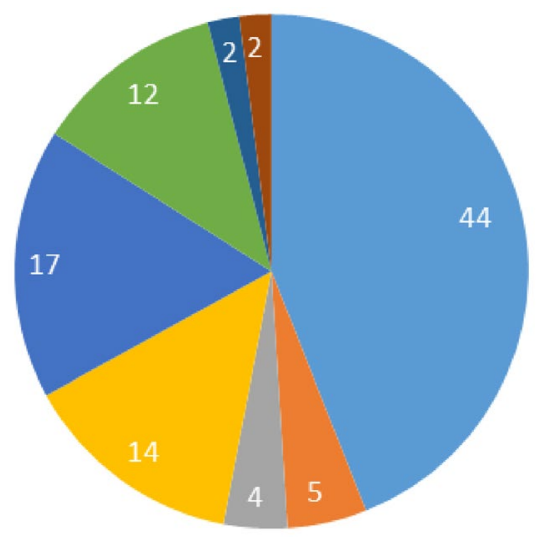

$\begin{array}{ll}\text { Food and green } & \text { Glass } \\ \text { Other } & \square \text { Paper and cardboard } \square \text { Plastic } \\ \text { nubber and leather } & \square \text { Wood }\end{array}$

Fig. 3 Composition of municipal solid waste (\%) [2]

\section{Aerogel from Paper Waste}

Paper and cardboard are the second most abundant types of municipal solid waste, making up $17 \%$ of the total. Approximately 419.7 million tons of paper and cardboard were produced in 2017, mainly for packaging and graphic usages [51]. Waste papers consist of approximately $40-80 \%$ of cellulose, $5-15 \%$ of hemicellulose and amounts of lignin and proteins [52]. In 2013, Nguyen et al. [28] introduced cellulose aerogels from paper waste. With an oil absorption capacity of $24 \mathrm{~g} / \mathrm{g}$ and its biodegradability, the cellulose aerogel from used paper is a potential candidate for oil spill cleaning. However, the aerogel takes up to 7 days to prepare with many stages, including dispersion of the fibers in $\mathrm{NaOH}$ and urea, freeze gelation, coagulation in ethanol, solvent exchange to water, freeze-drying and hydrophobic coating. In 2014, Feng et al. [27] simplified the preparation of cellulose aerogels from paper by employing Kymene as a crosslinker. Compared to the $\mathrm{NaOH} /$ urea method, this new approach reduces the synthesis duration from 7 days to 3 days and eliminates toxic chemicals in the procedure. Moreover, the resulting aerogels have an oil absorption capacity of $95 \mathrm{~g} / \mathrm{g}, 4$ times higher than the previously reported cellulose aerogels [28]. The oil absorption of the fabricated aerogels exhibits $\mathrm{pH}$ insensitivity under different simulated conditions with

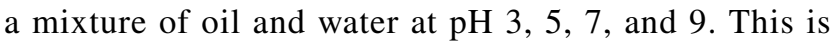
because the high porosity of the aerogels and oil viscosity are independent of the environmental $\mathrm{pH}$ values. It is witnessed that the aerogels absorb oil quickly in only $7 \mathrm{~min}$ when they are placed on the top of the oil-contaminated seawater (Fig. 4).
Different types of paper are utilized in the fabrication of cellulose aerogels such as newspapers [36, 37], cardboards [33] and office papers [35] with various applications including fire retardant, oil and solvent absorption and pollutant removal. Besides, paper can replace toxic organic precursors to prepare carbon aerogels. Li et al. [32] reported elastically compressible and conductive carbon aerogels from waste paper using "oxidization-oven drying-carbonization" method, which is superior to the freeze-drying approach. In this work, waste paper pulp is oxidized by sodium chlorite, filtrated and oven dried to form the sodium chlorite/waste paper aerogels and pyrolyzed at $1000{ }^{\circ} \mathrm{C}$ to form carbon aerogels. These works show high potential of paper and cardboard waste for being used as a source of carbon and cellulose.

\section{Aerogel from Plastic Waste}

Plastic waste accounts for $12 \%$ of the total municipal solid waste. Over 300 million tons of plastic are produced annually, in which at least 8 million tons end up in water and deep-sea sediments [53]. It is not surprising that single-use plastics are one of the most common items found on beaches all over the world. Plastic production is expected to reach 8.3 billion tons by 2050 [54]. During the COVID-19 crisis in the first half of 2020, a growing reliance on food delivery services created a jump of plastic waste from 5,500 tons to 6,300 tons per day in Thailand [55]. However, recycling rates of plastic are relatively low, at around $30 \%$ in developed countries and close to $0 \%$ in developing countries [54]. Recycling plastic waste by remelting and reforming, downgrades the quality of plastics due to thermal degradation of polymer chains and thus low-grade and low-value secondary plastics are obtained. In 2018, recycled polyethylene terephthalate (rPET) aerogels from plastic bottles were introduced. The aerogel network is formed by hydrogen bonds between rPET fiber and poly(vinyl alcohol) (PVA), and acetal bonds between rPET fiber and glutaraldehyde [38]. The rPET aerogels show a hydrophobicity with water contact angles of $120.7^{\circ}-149.8^{\circ}$, and a high elasticity with a low compressive Young's modulus (1.16-2.87 kPa). They have a low thermal conductivity $(35-38 \mathrm{~mW} / \mathrm{mK})$ and a high acoustic absorption with a noise reduction coefficient (NRC) of 0.45 , higher than that of the commercial acoustic foam absorber with the same thickness. After coating with methyltrimethoxysilane (MTMS), the rPET aerogels can then be used as an oil and organic solvent absorber [39] (Fig. 5). The MTMS-coated rPET aerogel with $1.0 \mathrm{wt} \%$ rPET fiber and $0.10 \mathrm{wt} \%$ PVA has a high oil absorption capacity of 80 times of its weight and takes around $10 \mathrm{~s}$ to reach its maximum absorption capacity, demonstrating its potential use in oil spill cleaning 
Table 1 Preparation and application of aerogels from municipal solid waste

\begin{tabular}{|c|c|c|c|c|c|}
\hline No. & Waste materials & Type of aerogels & Fabrication process & Properties/applications $^{\mathrm{a}}$ & References \\
\hline 1 & Paper & Cellulose & $\begin{array}{l}\text { Dispersion } \\
\text { Gelation } \\
\text { Solvent exchange } \\
\text { Freeze-drying } \\
\text { Silanization }\end{array}$ & Oil absorption: $24 \mathrm{~g}$ crude oil/g & [28] \\
\hline 2 & Paper & Cellulose & $\begin{array}{l}\text { Dispersion } \\
\text { Gelation } \\
\text { Solvent exchange } \\
\text { Freeze-drying }\end{array}$ & $\begin{array}{l}\text { Water absorption: } 19 \mathrm{~g} / \mathrm{g} \\
\text { Thermal insulation: } 29-32 \mathrm{~mW} / \\
\mathrm{mK}\end{array}$ & [29] \\
\hline 3 & Paper & Cellulose & $\begin{array}{l}\text { Dispersion } \\
\text { Freeze-drying } \\
\text { Crosslinking } \\
\text { Silanization }\end{array}$ & $\begin{array}{l}\text { Oil absorption: } 95 \mathrm{~g} \text { motor oil/g } \\
\text { Thermal insulator }\end{array}$ & {$[27,30]$} \\
\hline 4 & Paper & Carbon & $\begin{array}{l}\text { Dispersion } \\
\text { Freeze-drying } \\
\text { Pyrolysis }\end{array}$ & $\begin{array}{l}\text { Oil and solvent absorption: } \\
188 \mathrm{~g} \text { pump oil/g; } 70 \mathrm{~g} \\
\text { tetrachloromethane/g } \\
\text { Emulsion separation } \\
\text { Sensors and pressure-sensitive } \\
\text { electronics }\end{array}$ & {$[31,32]$} \\
\hline 5 & Paper and cardboard & Cellulose & $\begin{array}{l}\text { Mixing with flame retardant } \\
\text { agent } \\
\text { Dispersion } \\
\text { Freeze-drying }\end{array}$ & Fire retardant & {$[33]$} \\
\hline 6 & Cardboard & Cellulose/sodium alginate & $\begin{array}{l}\text { Dispersion } \\
\text { Crosslinking } \\
\text { Freeze-drying } \\
\text { Stearic acid modification }\end{array}$ & $\begin{array}{l}\text { Oil and solvent absorption: } \\
47 \mathrm{~g} \text { tetrachloroethane/g; } 34 \mathrm{~g} \\
\text { kerosene/g }\end{array}$ & [34] \\
\hline 7 & Office paper & Cellulose/chitosan & $\begin{array}{l}\text { Dispersion } \\
\text { Freeze-drying }\end{array}$ & $\begin{array}{l}\text { Metal ion adsorption: } 156.3 \mathrm{mg} \\
\mathrm{Cu}^{2+/} \mathrm{g}\end{array}$ & [35] \\
\hline 8 & Newspaper & Cellulose & $\begin{array}{l}\text { Ink and glue removal } \\
\text { Dispersion } \\
\text { Freeze-drying }\end{array}$ & Dye absorption & [36] \\
\hline 9 & Newspaper & Cellulose & $\begin{array}{l}\text { Ink and glue removal } \\
\text { Dispersion } \\
\text { Freeze-drying } \\
\text { Silanization }\end{array}$ & $\begin{array}{l}\text { Oil and solvent absorption: } 44 \mathrm{~g} \\
\text { chloroform/g; } 33 \mathrm{~g} \text { kerosene/g } \\
\text { Lampblack filtration }\end{array}$ & [37] \\
\hline 10 & Plastic bottle & Polyethylene-terephthalate & $\begin{array}{l}\text { Dispersion } \\
\text { Freeze-drying }\end{array}$ & $\begin{array}{l}\text { Thermal insulation: } 35-38 \mathrm{~mW} / \\
\mathrm{mK} \\
\text { Acoustic insulation }\end{array}$ & {$[38]$} \\
\hline 11 & Plastic bottle & Polyethylene-terephthalate & $\begin{array}{l}\text { Dispersion } \\
\text { Freeze-drying } \\
\text { Silanization }\end{array}$ & Oil absorption: $79.4 \mathrm{~g}$ oil/g & [39] \\
\hline 12 & Plastic bottle & Polyethylene-terephthalate/Silica & $\begin{array}{l}\text { Dispersion } \\
\text { Gelation } \\
\text { Solvent exchange } \\
\text { Silylation } \\
\text { Ambient pressure drying }\end{array}$ & $\begin{array}{l}\text { Thermal insulation: } 37-47 \mathrm{~mW} / \\
\mathrm{mK}\end{array}$ & {$[40]$} \\
\hline 13 & Rubber tire & Rubber & $\begin{array}{l}\text { Dispersion } \\
\text { Freeze-drying } \\
\text { Silanization }\end{array}$ & $\begin{array}{l}\text { Thermal insulation: } 35-49 \mathrm{~mW} / \\
\mathrm{mK} \\
\text { Acoustic insulation } \mathrm{NRC}=0.41- \\
0.56 \\
\text { Oil absorption: } 19.3-25 \mathrm{~g} \text { oil } / \mathrm{g}\end{array}$ & {$[41-43]$} \\
\hline 14 & Cotton fabrics & Cellulose & $\begin{array}{l}\text { Dispersion } \\
\text { Freeze-drying } \\
\text { Crosslinking }\end{array}$ & Stopping liquid leakage & [44] \\
\hline 15 & Cotton fabrics & Cellulose $/ \mathrm{Mg}(\mathrm{OH})_{2}$ & $\begin{array}{l}\text { Dispersion } \\
\text { Freeze-drying } \\
\text { Crosslinking }\end{array}$ & $\begin{array}{l}\text { Thermal insulation: } 56-81 \mathrm{~mW} / \\
\mathrm{mK}\end{array}$ & [45] \\
\hline
\end{tabular}


Table 1 (continued)

\begin{tabular}{|c|c|c|c|c|c|}
\hline No. & Waste materials & Type of aerogels & Fabrication process & Properties/applications $^{\mathrm{a}}$ & References \\
\hline 16 & Cotton fabrics & Carbon/carbon oxide & $\begin{array}{l}\text { Dispersion } \\
\text { Dehydrating } \\
\text { Drying } \\
\text { Pyrolysis } \\
\text { Oxidizing }\end{array}$ & $\begin{array}{l}\text { Pollutant absorption: } 1519 \mathrm{mg} \\
\text { methylene blue/g } \\
\text { Metal ion adsorption: } 111.1 \mathrm{mg} \\
\mathrm{Pb}^{2+/} \mathrm{g}\end{array}$ & [46] \\
\hline 17 & Denim & Cellulose & $\begin{array}{l}\text { Dissolving in ionic liquid } \\
\text { Regeneration } \\
\text { Drying }\end{array}$ & Not mentioned & {$[47]$} \\
\hline 18 & Cigarette filter & Carbon & $\begin{array}{l}\text { Graphene oxide coating } \\
\text { Ambient pressure drying } \\
\text { Carbonization } \\
\text { Polypyrrole coating } \\
\text { Ambient pressure drying }\end{array}$ & Electromagnetic wave absorption & [48] \\
\hline 19 & Bamboo chopstick & Carbon & $\begin{array}{l}\text { Carbonization } \\
\text { Dispersion } \\
\text { Freeze-drying } \\
\text { Pyrolysis }\end{array}$ & $\begin{array}{l}\text { Oil and solvent adsorption: } 129 \mathrm{~g} \\
\text { pump oil } / \mathrm{g} ; 80 \mathrm{~g} \text { chloroform } / \mathrm{g}\end{array}$ & [49] \\
\hline 20 & Aluminum foil & Aluminum hydroxide & $\begin{array}{l}\text { Dispersion } \\
\text { Precipitation } \\
\text { Gelation } \\
\text { Freeze-drying }\end{array}$ & $\begin{array}{l}\text { Thermal insulation: } 28-32 \mathrm{~mW} / \\
\mathrm{mK}\end{array}$ & {$[50]$} \\
\hline
\end{tabular}

${ }^{a}$ Specifications to illustrate for applications: absorption capacity (for absorption), adsorption capacity (for adsorption), thermal conductivity (for thermal insulation)

Fig. 4 Oil absorption performance of paper aerogel in artificial seawater environment. Reprinted from Feng et al. [30], Copyright (2015) with permission from Elsevier

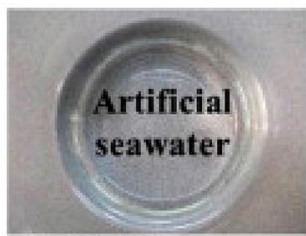

Artificial seawater $(3.5 \% \mathrm{NaCl}, \mathrm{pH} 7)$

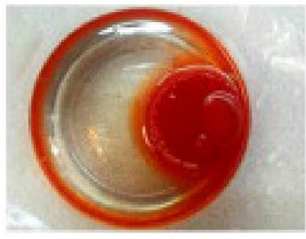

$7 \mathrm{~min}$

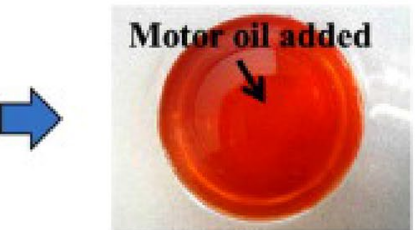

Artificial seawater + Motor oil

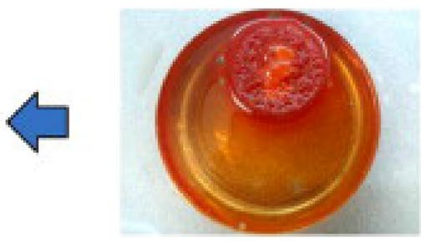

5 min

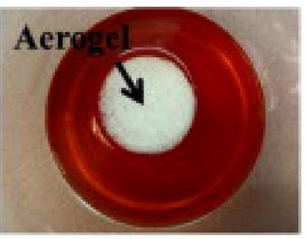

Artificial seawater + Motor oil + Aerogel

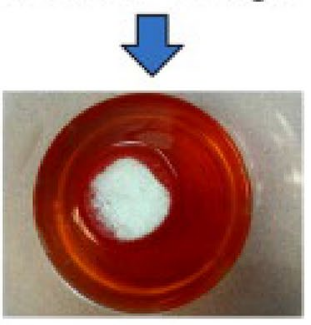

$1 \mathrm{~min}$ applications. After being used for oil spill cleaning, the PET aerogel can release the absorbed oil by a simple squeezing method without any significant decrease in its absorption capacity after five absorption-recollection cycles. Recycling water bottles into PET aerogels not only encourages a circular economy, but also offers sustainable solutions for technical challenges such as heat and sound insulation and oil absorption.

\section{Aerogel from Rubber Waste}

Due to the growing transport demand, over 1.7 billion new tires are produced per year. The figure for waste tires generated per year is over 1 billion, of which only $3-15 \%$ are recycled [56]. The car tires are mainly composed of synthetic polymers including nylon 6 , nylon 6-6, dacron and rayon. The polymer contents in the car tires are difficult to 
Fig. 5 Recycling of PET fibers into hydrophobic rPET aerogel for oil spill cleaning. Reprinted from Le et al. [39], Copyright (2020) with permission from Elsevier

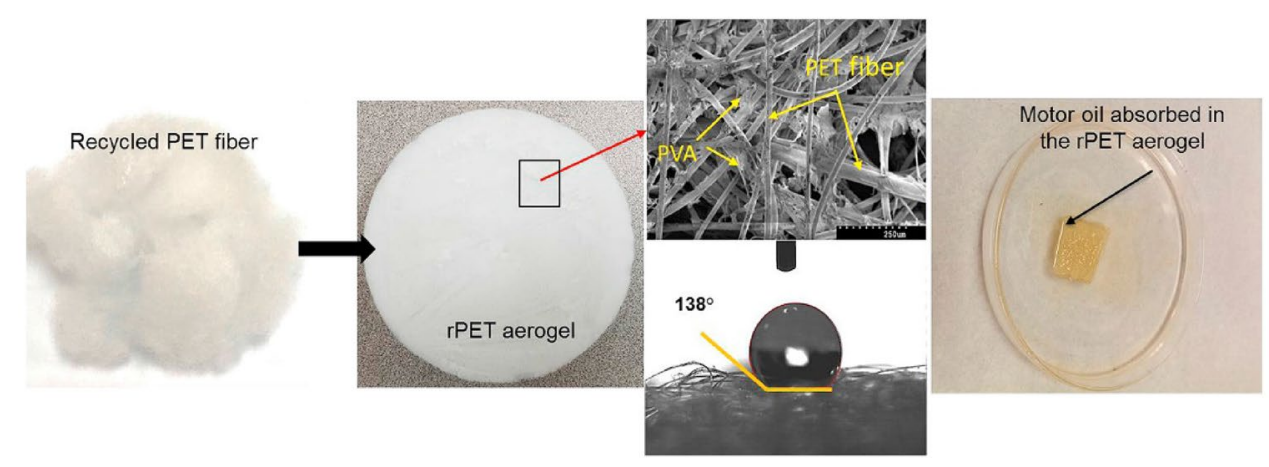

dissolve with green solvents. One strategy to obtain the gel mixture of rubber is employing crosslinkers namely acetone, PVA and glutaraldehyde. Briefly, car tire fibers were dispersed into acetone/PVA/glutaraldehyde/water, followed by heat curing and freeze-drying to create durable aerogels as shown in Fig. 6 [41]. Functional groups on polymer chains of rubber are utilized to form crosslinks with acetone, PVA and glutaraldehyde via hydrogen bonds. The developed rubber aerogels are both flexible and durable with a high Young's modulus up to $965.6 \mathrm{kPa}$, allowing them to spring back to their original shape instead of being deformed plastically after compression. The high elasticity of rubber aerogels is significantly useful compared to the brittleness of the conventional silica aerogels in terms of functioning in harsh environments with high mechanical impacts. Multiple applications of the rubber aerogels are demonstrated, such as thermal insulation $(\mathrm{K}=35-47 \mathrm{~mW} / \mathrm{mK})$, sound insulation $(\mathrm{NRC}=0.41$ ) and oil absorption (up to $25.0 \mathrm{~g} / \mathrm{g}$ ). The rubber aerogels' maximum oil absorption is approximately 1.7 and 2.8 times higher than that of commercial polypropylene mats and nonwoven polypropylene, respectively [56].

\section{Aerogel from Textile Waste}

Recycled textiles are another abundant precursor for cellulose-based aerogels. With the rapid development of "fast fashion" involving the mass production of low-cost clothing with short lifetime, the global production of cotton reached
Fig. 6 Fabrication and properties of rubber aerogels from car tire waste. Reprinted from Thai et al. [41], Copyright (2019) with permission from Elsevier

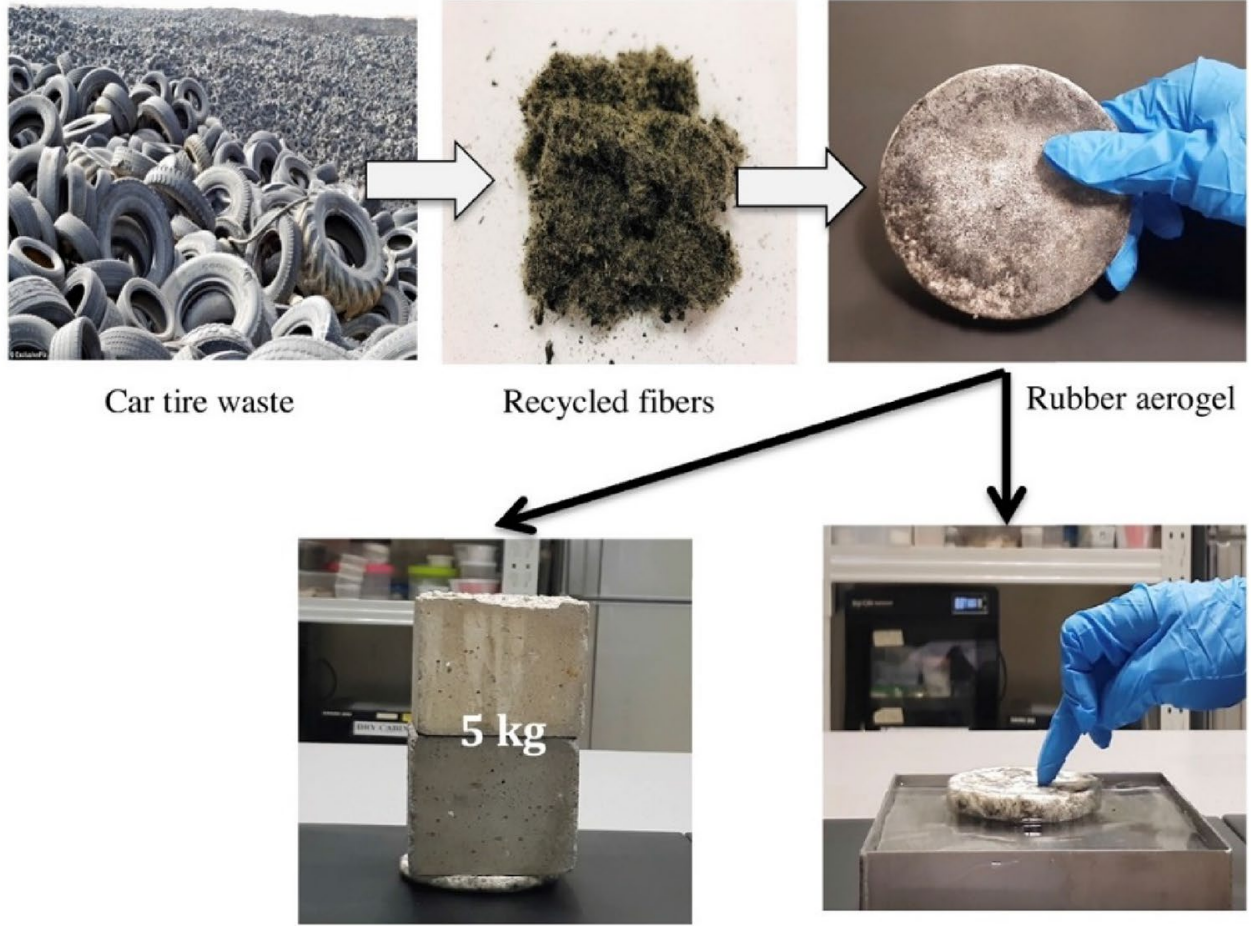

Rubber aerogel can stand easily $5-\mathrm{kg}$ bricks without its structure damage.
Ultralight rubber aerogel is floating on water surface. 
27.3 million tons in 2018 [57]. To utilize used clothing and leftover materials from textile industry, Han et al. [45] prepared hybrid cellulose/magnesium hydroxide nanoparticles aerogels from waste cotton fabric. The magnesium hydroxide nanoparticles are synthesized in situ in the gel structure, which enhance the flame retardancy of the composite aerogels. Duong et al. [44] developed compressed hybrid cotton aerogels from cotton and cellulose fibers using Kymene as a crosslinker. With the ability to volumetrically expand 16 times within $4.5 \mathrm{~s}$, the aerogels possess potential applications in hemostatic devices, oil-spill cleaning and personal care. The better mechanical handleability of the cotton aerogels in contrast to aerogels from paper waste is attributed to the higher mechanical properties of cotton fibers compared to the delignificated wood fibers [58]. With good mechanical strength, high cellulose content and relatively long fibers, cotton fibers from fabric waste can be utilized to assemble aerogel scaffolds for multiple applications. Similar to the mentioned textile wastes, wool waste fibers were recycled into advanced aerogels to minimize their disposal and incineration. The aerogels were fabricated by using PVA to bind the wool waste fibers, freeze-drying and surface modification with methyltriethoxysilane. The prepared aerogels show a significantly high oil absorption capacity of $136.2 \mathrm{~g} / \mathrm{g}$ that was 15 times greater than commercial polypropylene absorbents [59].

\section{Aerogels from Agricultural Waste}

Agricultural waste is defined as non-product outputs of the agricultural processing and production. They can be generated from cultivation activities, livestock production, aquaculture and food processing [60]. Conventionally, agricultural waste is managed by open burning or landfilling, resulting in harmful gases and organic substances released. Despite being considered low-value by-products, agricultural wastes are abundant sources of raw materials such as cellulose [61, 62], silica [63] and bioactive compounds [64]. Therefore, many works of utilizing agricultural waste as precursors for aerogels have been conducted.

\section{Aerogels from Rice Husk Ash}

Worldwide rice production is estimated to be 700 million tons in 2015 , releasing approximately 140 million tons of rice husks during the milling process. Chemical composition of the rice husks includes cellulose (50\%), lignin $(25 \%-30 \%)$, silica $(15 \%-20 \%)$, and moisture $(10 \%-15 \%)$ [65]. Burning of rice husk results in rice husk ash containing around $90 \%$ of silica, which can be used as a precursor for silica aerogels [66]. Remarkably, Green Earth Aerogels Technologies (Spain) successfully produced commercial silica aerogels from rice husk ash [67]. Table 2 shows some approaches to silica aerogels with various morphologies from rice husk ash. Generally, rice husk ash is converted into sodium silicate by reacting with hot $\mathrm{NaOH}$ solution. The resulting mixture is gelated by an acid and aged to obtain a silica hydrogel. Subsequently, water in the gel is replaced by other volatile solvents. Finally, the aerogel is obtained by supercritical drying or ambient pressure drying. The density, pore volume, pore size and surface area of aerogels from rice husk ash are comparable to those of aerogels prepared by traditional methods [68]. As can be seen, the pore volume, pore size and surface area of the supercritical-dried silica aerogels are slightly larger than those of the ambient pressure dried ones [69]. It can be explained by the elimination of surface tension during supercritical drying, compared to the partial reduction of surface tension by silylation in ambient pressure drying technique.

\section{Aerogels from Fruit and Vegetable Waste}

Fruit and vegetable harvesting and processing release various residues including pods, peel, pulp, stones, and seeds. These residues mainly contain soluble sugars, hydrolysable materials and fibers [77]. Common utilizations of fruit and vegetable waste are chemical production by extraction or fermentation and adsorption in waste water treatment [78]. Furthermore, fruit and vegetable waste have been utilized to prepare aerogels as shown in Table 3.

As seen, cellulose and carbon aerogels are the two most popular types of aerogels from these biomass residues. Cellulose aerogels can be obtained from pineapple leaves, sugarcane bagasse or coconut shells. Because of numerous hydroxyl groups on the cellulose chains of pineapple leaf fibers, PVA binder is used to create the hydrogen bonding between the fibers in the first pineapple aerogels developed by Luu et al. [95] and Do et al. [80] (Fig. 7a). The synthesized aerogels exhibit a low thermal conductivity (30-34 $\mathrm{mW} / \mathrm{mK}$ ) and can be used as fillers in thermal jackets to maintain the water temperature. The results show that the developed thermal jacket from pineapple aerogels can keep ice slurry from $-3{ }^{\circ} \mathrm{C}$ below $0{ }^{\circ} \mathrm{C}$ for $6 \mathrm{~h}$, and hot water from $90{ }^{\circ} \mathrm{C}$ above $40{ }^{\circ} \mathrm{C}$ for $2.5 \mathrm{~h}$, which is about three times better than a commercial product in terms of thermal insulation (Fig. 7b). Moreover, the 190-g thermal jacket shows the great potential to replace expensive and heavy $900-\mathrm{g}$ vacuum thermos flasks. Functionalized pineapple leaf-derived aerogels with the presence of activated carbon show their ability in fruit preservation with ethylene gas adsorption capacity of $1.08 \mathrm{mmol} / \mathrm{g}$ at atmospheric pressure. The aerogels after coating with diethylenetriamine are also applied in treatment of contaminated wastewater with the maximum nickel ion adsorption uptake of $0.835 \mathrm{mmol} / \mathrm{g}$ [81]. Wan et al. [83] prepared cellulose aerogels from coconut shell for dealing 
Table 2 Preparation and physical properties of silica aerogels from rice husk ash

\begin{tabular}{|c|c|c|c|c|c|c|c|}
\hline No. & Type of silica aerogels & Fabrication process & $\begin{array}{l}\text { Density } \\
\left(\mathrm{g} / \mathrm{cm}^{3}\right)\end{array}$ & Pore volume $\left(\mathrm{cm}^{3} / \mathrm{g}\right)$ & Pore size $(\mathrm{nm})$ & Surface area $\left(\mathrm{m}^{2} / \mathrm{g}\right)$ & Referencess \\
\hline 1 & Monolith & $\begin{array}{l}\text { Silicate extraction } \\
\text { Silylation by TMOS } \\
\text { Gelation by acid } \\
\text { Solvent exchange with } \\
\text { ethanol } \\
\text { Ambient drying }\end{array}$ & $0.32-0.33$ & $0.78-3.31$ & $5-60$ & $315-500$ & {$[70,71]$} \\
\hline 2 & Monolith & $\begin{array}{l}\text { Silicate extraction } \\
\text { Gelation by acid } \\
\text { Solvent exchange with } \\
\text { ethanol } \\
\text { Silylation by TEOS } \\
\text { Solvent exchange with } \\
\text { n-hexane } \\
\text { Ambient drying }\end{array}$ & 0.67 & 3.1 & $10-40$ & 273 & [72] \\
\hline 3 & Monolith & $\begin{array}{l}\text { Silicate extraction } \\
\text { Gelation by resin/acid } \\
\text { Solvent exchange with } \\
\text { ethanol } \\
\text { ScCO2 drying }\end{array}$ & $0.038-0.071$ & $3.39-8.65$ & $10-60$ & $598-730$ & {$[73,74]$} \\
\hline 4 & Bead & $\begin{array}{l}\text { Silicate extraction } \\
\text { Gelation by acid } \\
\text { Solvent exchange with } \\
\text { ethanol } \\
\text { Silylation } \\
\text { Ambient pressure drying }\end{array}$ & 0.055 & N/A & N/A & 773 & [75] \\
\hline 5 & Microsphere & $\begin{array}{l}\text { Silicate extraction } \\
\text { Emulsification with sur- } \\
\text { factants } \\
\text { Settling } \\
\text { Solvent exchange with } \\
\text { ethanol } \\
\mathrm{ScCO}_{2} \text { drying }\end{array}$ & N/A & 1.7 & 20 & 340 & [76] \\
\hline
\end{tabular}

with chemical leaks and oil spills. By surface modification with methyltrichlorosilane, the aerogels can adsorb solvents and oil of the amount as high as 296-669 times of their own weight, which is significantly higher than the oil absorption capacity of the hydrophobic pineapple aerogels (37.9 times) [79]. The high tensile strength and relatively long cellulose chains give plant fibers the ability to assemble into flexible aerogel sheets, which can be easily rolled up for transportation, storage, and usage in different situations.

Organic substances from fruit and vegetable residues such as bagasse, peels and leaves can be used as inexpensive and abundant carbon sources for carbon aerogels. Zhu et al. [56] prepared carbon aerogels from pomelo peels via a three-step procedure including hydrothermal carbonization, freezedrying and pyrolysis. The aerogels possess a high specific area of $466.0-759.7 \mathrm{~m}^{2} / \mathrm{g}$ and a high absorption capacity up to 36 times of their weight for various oil and organic solvents. Carbon aerogels from fruits and vegetables waste can be also designed for electronic devices such as capacitors and batteries. For instance, Cai et al. [86] reported carbon aerogels from cabbage leaves with a superior capacitance of $291 \mathrm{~F} / \mathrm{g}$ and large capacitance retention of $96.76 \%$ over 10,000 cycles.

Interestingly, sugarcane bagasse can be processed in different pathways to obtain cellulose aerogels, carbon aerogels or silica aerogels. Dispersing sugarcane fibers in PVA, followed by freeze-drying and heat curing results in cellulose aerogels [82]. The aerogels after modification with MTMS have high hydrophobicity without affecting their porosity. A low thermal conductivity of $31-42 \mathrm{~mW} / \mathrm{mK}$ and an oil absorption capacity of $25 \mathrm{~g} / \mathrm{g}$ indicate potential applications of the aerogels in spill cleaning and heat insulation. Hao et al. prepared cellulose aerogels from bagasse via a freezedrying approach, then pyrolyzed and activated the resulting aerogels to obtain carbon aerogels [85]. These carbon aerogels possess a comparable high specific capacitance of $142.1 \mathrm{~F} / \mathrm{g}$ and an excellent capacitance retention of $93.9 \%$ over 5000 cycles, which are suitable for supercapacitor electrodes. Nazriati et al. utilized the bagasse ash in sugarcane factories as a silica source for the preparation of hydrophobic silica aerogels [89]. This approach involves surface modification of wet gels and ambient pressure drying. The 
Table 3 Preparation and application of aerogels from fruits and vegetables waste

\begin{tabular}{|c|c|c|c|c|c|}
\hline No. & Waste materials & Type of aerogels & Fabrication process & Properties/applications ${ }^{\mathrm{a}}$ & References \\
\hline 1 & $\begin{array}{l}\text { Pineapple } \\
\text { leaves }\end{array}$ & Cellulose & $\begin{array}{l}\text { Dispersion } \\
\text { Freeze-drying } \\
\text { Silanization }\end{array}$ & Oil absorption: $37.9 \mathrm{~g} / \mathrm{g}$ & [79] \\
\hline 2 & $\begin{array}{l}\text { Pineapple } \\
\text { leaves }\end{array}$ & Cellulose & $\begin{array}{l}\text { Dispersion } \\
\text { Freeze-drying }\end{array}$ & $\begin{array}{l}\text { Thermal insulation: } 30-34 \mathrm{~mW} / \mathrm{mK} \\
\text { Acoustic insulation }\end{array}$ & {$[80]$} \\
\hline 3 & Pineapple leaves & Cellulose & $\begin{array}{l}\text { Dispersion } \\
\text { Gelation } \\
\text { Freeze-drying }\end{array}$ & $\begin{array}{l}\text { Gas adsorption: } 1.08 \mathrm{mmol} \text { ethylene/g } \\
\text { Metal ion adsorption: } 0.835 \mathrm{mmol} \\
\mathrm{Ni}^{2+} / \mathrm{g}\end{array}$ & {$[81]$} \\
\hline 4 & Sugarcane bagasse & Cellulose & $\begin{array}{l}\text { Dispersion } \\
\text { Freeze-drying } \\
\text { Silanization }\end{array}$ & $\begin{array}{l}\text { Oil absorption: } 25 \mathrm{~g} / \mathrm{g} \\
\text { Thermal insulation: } 31-42 \mathrm{~mW} / \mathrm{mK}\end{array}$ & {$[82]$} \\
\hline 5 & Coconut shell & Cellulose & $\begin{array}{l}\text { Dispersion } \\
\text { Solvent exchange to t-BuOH } \\
\text { Gelation } \\
\text { Freeze-drying } \\
\text { Silanization }\end{array}$ & $\begin{array}{l}\text { Oil and solvent adsorption: } 669 \mathrm{~g} \text { motor } \\
\text { oil/g, } 425 \mathrm{~g} \text { t-BuOH/g }\end{array}$ & {$[83]$} \\
\hline 6 & Durian shell & Carbon & $\begin{array}{l}\text { Carbonization } \\
\text { Freeze-drying } \\
\text { Pyrolysis }\end{array}$ & $\begin{array}{l}\text { Oil and solvent adsorption: } 19.5 \mathrm{~g} \text { sun- } \\
\text { flower oil } / \mathrm{g}, 18.6 \mathrm{~g} \text { formic acid/g }\end{array}$ & [84] \\
\hline 7 & Sugarcane bagasse & Carbon & $\begin{array}{l}\text { Dispersion } \\
\text { Freeze-drying } \\
\text { Pyrolysis } \\
\text { Activation }\end{array}$ & Energy storage & {$[85]$} \\
\hline 8 & Cabbage leaves & Carbon & $\begin{array}{l}\text { Carbonization } \\
\text { Freeze-drying } \\
\text { Pyrolysis }\end{array}$ & $\begin{array}{l}\text { Energy storage } \\
\text { Oil and solvent absorption: } 202 \text { g pump } \\
\text { oil/g; } 165 \text { g cyclohexane/g }\end{array}$ & {$[86]$} \\
\hline 9 & Banana peels & Carbon-Cellulose & $\begin{array}{l}\text { Dispersion } \\
\text { Freeze-drying } \\
\text { Pyrolysis }\end{array}$ & $\begin{array}{l}\text { Oil and solvent absorption: } 115 \mathrm{~g} \text { pump } \\
\text { oil/g, } 86 \mathrm{~g} \text { chloroform/g } \\
\text { Emulsion separation }\end{array}$ & [87] \\
\hline 10 & Pomelo peels & Carbon & $\begin{array}{l}\text { Carbonization } \\
\text { Freeze-drying } \\
\text { Pyrolysis }\end{array}$ & $\begin{array}{l}\text { Oil and solvent absorption: } 36 \mathrm{~g} \text { sun- } \\
\text { flower oil/g, } 31 \mathrm{~g} \text { formic acid/g }\end{array}$ & {$[56]$} \\
\hline 11 & Pomelo peels & $\begin{array}{l}\text { Nitrogen/boron/ } \\
\text { carbon }\end{array}$ & $\begin{array}{l}\text { Carbonization } \\
\text { Freeze-drying } \\
\text { Impregnating } \\
\text { Freeze-drying } \\
\text { Pyrolysis }\end{array}$ & Energy storage & {$[88]$} \\
\hline 12 & Sugarcane bagasse ash & Silica & $\begin{array}{l}\text { Dissolving } \\
\text { Silylation } \\
\text { Dispersion } \\
\text { Gelation } \\
\text { Ambient pressure drying }\end{array}$ & $\begin{array}{l}\text { Pore volume: } 0.75-2.16 \mathrm{~cm} 3 / \mathrm{g} \\
\text { Pore size: } 3.39-7.38 \mathrm{~nm} \\
\text { Surface area: } 450-1114 \mathrm{~m} 2 / \mathrm{g}\end{array}$ & [89] \\
\hline 13 & Coffee grounds & Coffee-cellulose & $\begin{array}{l}\text { Dispersion } \\
\text { Freeze-drying } \\
\text { Silanization }\end{array}$ & $\begin{array}{l}\text { Thermal insulation: } 37-45 \mathrm{~mW} / \mathrm{mK} \\
\text { Oil absorption: } 16 \mathrm{~g} \text { oil } / \mathrm{g}\end{array}$ & [90] \\
\hline 14 & Jackfruit and durian & Carbon & $\begin{array}{l}\text { Carbonization } \\
\text { Freeze-drying } \\
\text { Pyrolysis }\end{array}$ & Energy storage & [91] \\
\hline 15 & Watermelon & Carbon & $\begin{array}{l}\text { Carbonization } \\
\text { Freeze-drying }\end{array}$ & Energy storage & [92] \\
\hline 16 & Wheat straw and okara & Konjac glucomannan-based & $\begin{array}{l}\text { Dispersion } \\
\text { Freeze-drying }\end{array}$ & Filtration & {$[93]$} \\
\hline 17 & Peanut hull & Peanut hull/graphene & $\begin{array}{l}\text { Dispersion } \\
\text { Carbonization } \\
\text { Freeze-drying }\end{array}$ & $\begin{array}{l}\text { Oil and solvent absorption: } 58 \mathrm{~g} \text { pump } \\
\text { oil/g, } 79 \mathrm{~g} \text { chloroform/g } \\
\text { Emulsion separation }\end{array}$ & [94] \\
\hline
\end{tabular}

${ }^{a}$ Specifications to illustrate for applications: Absorption capacity (for Absorption), Adsorption capacity (for Adsorption), Thermal conductivity (for Thermal insulation) 
(a)

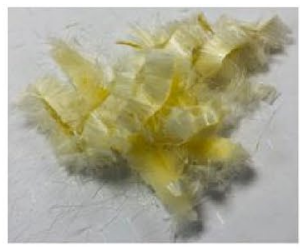

Raw material

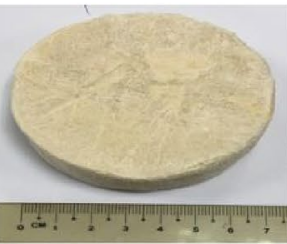

PFs aerogel

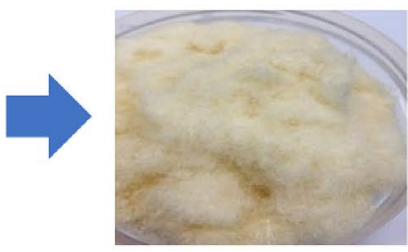

Blending

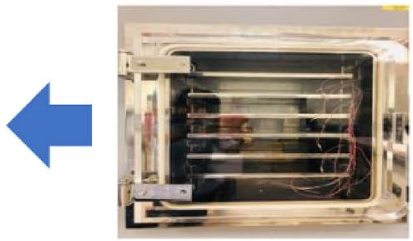

Freeze-drying

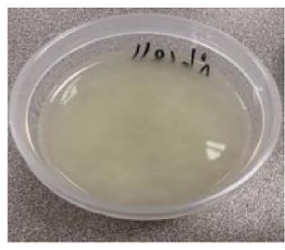

Mixing
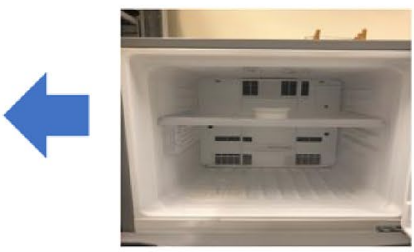

Freezing

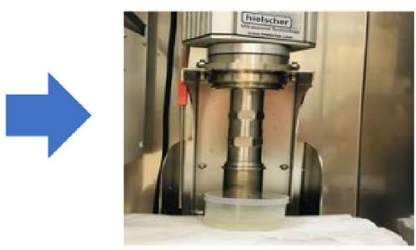

Sonicating
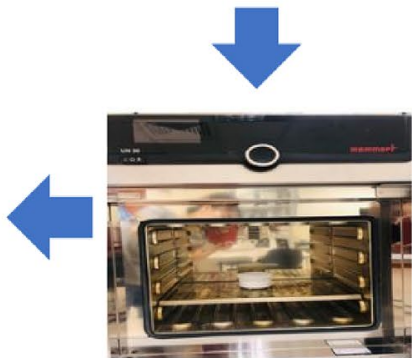

Curing

(b)
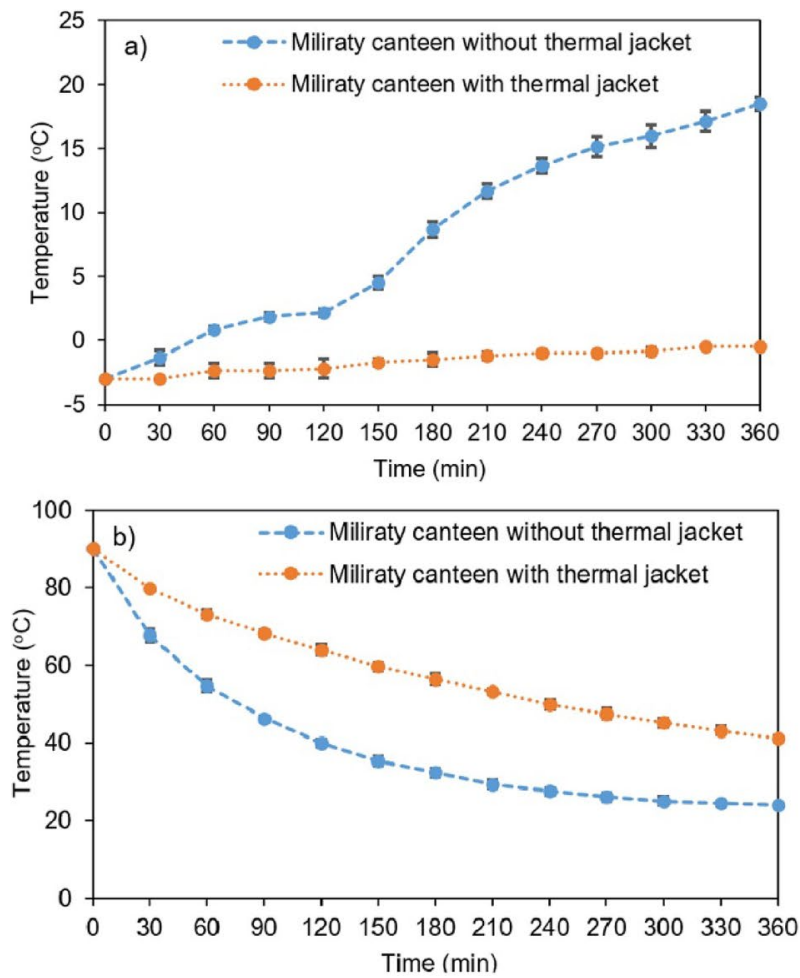

Fig. 7 a Fabrication of the pineapple fibers aerogel from pineapple leaves. Reprinted from Luu et al. [95]; b heat insulation performance of the thermal jacket made of pineapple aerogel. Reprinted from Do et al. [80], Copyright (2020) with permission from Elsevier

surface area and pore volume achieved can be up to 1114 $\mathrm{m}^{2} / \mathrm{g}$, and $2.16 \mathrm{~cm}^{3} / \mathrm{g}$, respectively.

\section{Aerogels from Industrial Waste}

The amount of industrial waste generated per day is approximately 17 times higher than that of the municipal waste from our daily activities [2]. Industrial waste is usually generated in massive amounts and requires further treatment before releasing to the environment. There have been some works on utilizing industrial waste into construction materials such as concrete [96], cement [97], and for water treatment [98]. Studies of aerogels from industrial waste is currently restricted to some certain types of waste. It might be due to 
the presence of hazardous substances such as alkali, acid, fluoride, cyanide, arsenic and heavy metal ions, making the pretreatment of raw materials costly and complex [99]. Some types of aerogels from industrial waste are tabulated in Table 4.

\section{Aerogels from Fly Ash}

Released from factories and thermal power plants, fly ash is an abundant source of silica, alumina and other metal oxides. It is estimated that 800 million tons of fly ash are generated in the world annually [115]. Fly ash can be converted into sodium silicate by hydrothermal reaction and then used as a precursor for silica aerogels, which considerably increases the economic value of the fly ash. Based on this concept, many studies on silica aerogels from fly ash have been conducted. A typical synthesis of silica aerogel from fly ash begins when fly ash is hydrothermally reacted with an acid and then filtrated. The residue is dissolved in hot $\mathrm{NaOH}$ solution to obtain sodium silicate solution. From this resulting solution, silica gel is prepared by adjusting $\mathrm{pH}$ with an acid or an ion exchange resin. After aging, the gel is immersed in anhydrous ethanol for solvent exchange. The hydrophilic surface can be modified by silylation via the reaction of the gel with trimethylchlorosilane in hexane/ ethanol. Finally, the gel is washed with hexane and dried at ambient pressure to achieve silica aerogels. The fly ash aerogels obtained via this approach possess a high water contact angle $\left(140^{\circ}-151^{\circ}\right)$, a large surface area (850-900 $\mathrm{m}^{2} / \mathrm{g}$ ) and a large pore size (12-24 nm), suggesting their potential applications in oil and organic pollutant removal. In addition, silica aerogels can also be prepared from coal gangue, dislodged sludge and gold mine waste. For instance, Zhu et al. [107] reported silica aerogels from coal gangue achieving a light weight $\left(0.19 \mathrm{~g} / \mathrm{cm}^{3}\right)$, a high specific surface area (above $600 \mathrm{~m}^{2} / \mathrm{g}$ ), a high porosity (> 90\%) and a low thermal conductivity $(20-25 \mathrm{~mW} / \mathrm{mK})$ as a potential candidate for thermal insulation. Duong et al. [105] developed a novel method to fabricate aerogels by using highly viscous and eco-friendly binders without the need for chemical pretreatment on fly ash. A stable and porous structure is created via hydrogen bonds between oxide particles in fly ash and hydroxyl groups on PVA chains (Fig. 8). Because of the high molecular weight of 89,000-90,000 and viscosity of 11.6$15.4 \mathrm{cP}\left(4 \%\right.$ in $\mathrm{H}_{2} \mathrm{O}$ at $\left.20^{\circ} \mathrm{C}\right)$, PVA can prevent fly ash particles from settling and distribute them evenly in the aerogels.

Another approach by Do et al. [106] was carried out by using a combination of industrial PVA with low viscosity and $\mathrm{CMC}$ as an anti-settlement agent to bind fly ash into a monolithic gel, followed by sublimation to obtain lightweight aerogels with porosity of 94.94-95.78\%. Both fabricated fly ash aerogels exhibited heat insulation with poor thermal conductivity $(40-50 \mathrm{~mW} / \mathrm{mK})$. Following the previous study, Do et al. [116] synthesized a multifunctional composite aerogel by consolidating two waste sources of fly ash and recycled plastic fibers. The novelty in this study is the use of xanthan gum at a low concentration of $0.4 \mathrm{wt} \%$ as a binder to adhere fly ash particles to the framework of plastic fibers and an anti-settling agent to avoid the sedimentation of fly ash. The as-fabricated composite aerogels are both excellent heat and sound insulation. Interestingly, although fly ash contains metal oxides, when it is converted into the composite aerogels, the heat conductivity of the materials is only from 34 to $39 \mathrm{~mW} / \mathrm{mK}$ along with their ultra-lightweight properties proved by their density and porosity of $0.026-0.062 \mathrm{~g} / \mathrm{cm}^{3}$ and $95.69-98.42 \%$, respectively. The addition of rPET fibers is found to enhance the compressive strength of the aerogels. Compared to the previous fly ash-based aerogels $[105,106]$, the developed composite aerogels are 5 times lighter and 1.5 times better in heat insulation at ambient condition. Overall, these works represent green methods to utilize $100 \%$ of fly ash without any chemical treatment, increasing the atom efficiency of the process and thus reducing the amount of waste generated.

\section{Aerogel from Leather Waste}

Leather industry releases around 6 million tons of solid waste annually [117]. Processing one ton of raw hides and skins produces $50 \mathrm{~kg}$ of raw trimmings, which contains approximately $20 \%$ collagen [118]. Utilizing skin trimming wastes, Mekonnen et al. [113] fabricated collagen-polypyrrole hybrid aerogels. The skin trimmings are pretreated to yield hide powder, dissolved in acetic acid solution to form a collagen solution and mixed with pyrrole. The mixture is undergone an oxidative polymerization by $\mathrm{FeCl}_{3}$ and sodium anthraquinone-2-sulfonate and then freeze-dried to obtain aerogels. The flexibility, brittleness, thermal stability, porosity, biocompatibility and electrical conductivity can be controlled by varying the concentration of polypyrrole in the aerogel matrix. It is suggested that the collagen-polypyrrole hybrid aerogels are potential candidates for various applications such as biosensor, tissue engineering, electrostatic discharge protection and electromagnetic interference shielding.

\section{Aerogel from Metal Waste}

Recycling metal waste into metal hydroxide aerogel is an advanced approach introducing by Yam et al. [114] (Fig. 9). Magnesium chips generated routinely in the machining process of casting are recycling into magnesium hydroxide aerogels. This fabrication employs PVA as a biodegradable binder and using freeze-drying method to obtain the aerogels. The $\mathrm{Mg}(\mathrm{OH})_{2}$ particles are formed in situ through dissolving magnesium metal 
Table 4 Preparation and application of aerogels from industrial waste

\begin{tabular}{|c|c|c|c|c|c|}
\hline No. & Waste materials & Type of aerogels & Fabrication process & Properties/applications $^{\mathrm{a}}$ & References \\
\hline 1 & Fly ash & Silica & $\begin{array}{l}\text { Calcination } \\
\text { Gelation } \\
\text { Solvent exchange to ethanol } \\
\text { Silylation } \\
\text { Ambient pressure drying }\end{array}$ & $\begin{array}{l}\text { Pore volume: } 2.92-4.875 \mathrm{~cm}^{3} / \mathrm{g} \\
\text { Pore size: } 4.875 \mathrm{~nm} \\
\text { Surface area: } 362.2-907.9 \mathrm{~m}^{2} / \mathrm{g}\end{array}$ & {$[100,101]$} \\
\hline 3 & Fly ash acid sludge & Silica & $\begin{array}{l}\text { Dissolving } \\
\text { Ion exchange } \\
\text { Gelation } \\
\text { Solvent exchange to ethanol } \\
\text { Silylation } \\
\text { Ambient pressure drying }\end{array}$ & $\begin{array}{l}\text { Pore volume: } 3.29-3.49 \mathrm{~cm}^{3} / \mathrm{g} \\
\text { Pore size: } 10.7-12.6 \mathrm{~nm} \\
\text { Surface area: } 700-850 \mathrm{~m}^{2} / \mathrm{g}\end{array}$ & {$[102,103]$} \\
\hline 4 & Fly ash & Titan dioxide/Silica-Alumina & $\begin{array}{l}\text { Calcination } \\
\text { Gelation } \\
\text { Solvent exchange to ethanol } \\
\text { Silylation } \\
\text { Ambient pressure drying } \\
\mathrm{TiO}_{2} \text { impregnation }\end{array}$ & Photocatalyst support & {$[104]$} \\
\hline 5 & Fly ash & Fly ash & $\begin{array}{l}\text { Dispersion } \\
\text { Freeze-drying }\end{array}$ & $\begin{array}{l}\text { Pore size: } 2-5 \mathrm{~nm} \\
\text { Thermal insulation: } 40-50 \mathrm{~mW} / \\
\mathrm{mK} \\
\text { Acoustic insulation }\end{array}$ & {$[105,106]$} \\
\hline 6 & Coal gangue & Silica & $\begin{array}{l}\text { Calcination } \\
\text { Gelation } \\
\text { Solvent exchange to ethanol } \\
\text { Silylation } \\
\text { Ambient pressure drying }\end{array}$ & $\begin{array}{l}\text { Pore size: } 20-27.5 \mathrm{~nm} \\
\text { Pore volume: } 4.81 \mathrm{~cm}^{3} / \mathrm{g} \\
\text { Surface area: } 600-690 \mathrm{~m} 2 / \mathrm{g} \\
\text { Thermal insulation: } 20-26.5 \\
\mathrm{~mW} / \mathrm{mK}\end{array}$ & {$[107,108]$} \\
\hline 7 & Dislodged sludge & Silica & $\begin{array}{l}\text { Dissolving } \\
\text { Ion exchange } \\
\text { Gelation } \\
\text { Solvent exchange to ethanol and } \\
\text { hexane } \\
\text { Silylation } \\
\text { Ambient pressure drying }\end{array}$ & $\begin{array}{l}\text { Pore volume: } 1.53-3.56 \mathrm{~cm}^{3} / \mathrm{g} \\
\text { Surface area: } 381-433 \mathrm{~m}^{2} / \mathrm{g} \\
\text { Pore size: } 7.07-23.40 \mathrm{~nm} \\
\text { Thermal insulation: } 30-32 \mathrm{~mW} / \\
\mathrm{mK}\end{array}$ & [109] \\
\hline 8 & Gold mine waste & Silica & $\begin{array}{l}\text { Dissolving } \\
\text { Silylation } \\
\text { Dispersion } \\
\text { Gelation } \\
\text { Ambient pressure drying }\end{array}$ & $\begin{array}{l}\text { Pore volume: } 0.45 \mathrm{~cm}^{3} / \mathrm{g} \\
\text { Pore size: } 2-100 \mathrm{~nm} \\
\text { Surface area: } 284 \mathrm{~m}^{2} / \mathrm{g}\end{array}$ & [110] \\
\hline 9 & Wood fibers & Cellulose & $\begin{array}{l}\text { Steam explosion } \\
\text { Dispersion } \\
\text { Freeze-drying } \\
\text { Silanization }\end{array}$ & Oil absorption: $19.5 \mathrm{~g} / \mathrm{g}$ & [111] \\
\hline 10 & Red mud & Cellulose/red mud & $\begin{array}{l}\text { Ball milling } \\
\text { Dispersion } \\
\text { Freeze-drying } \\
\text { Crosslinking }\end{array}$ & $\begin{array}{l}\text { Pollutant absorption: } 30 \mathrm{~g} \\
\text { 2,4-dichlorophenol/g } \\
\text { Thermal insulation: } 17-23 \mathrm{~W} / \\
\mathrm{mK} \\
\text { Acoustic insulation }\end{array}$ & [112] \\
\hline 11 & Animal skin trimmings & Collagen/polypyrrole & $\begin{array}{l}\text { Dissolving } \\
\text { Dispersion } \\
\text { Polymerization } \\
\text { Freeze-drying }\end{array}$ & Bioelectronics & [113] \\
\hline 12 & Magnesium chips & Magnesium hydroxide & $\begin{array}{l}\text { Dispersion } \\
\text { Precipitation } \\
\text { Gelation } \\
\text { Freeze-drying }\end{array}$ & $\begin{array}{l}\text { Thermal insulation: } 30-42 \mathrm{~mW} / \\
\mathrm{mK} \\
\text { Acoustic insulation }\end{array}$ & [114] \\
\hline
\end{tabular}

${ }^{a}$ Specifications to illustrate for applications: absorption capacity, g/g (for absorption), adsorption capacity, mg/g (for adsorption), thermal conductivity, $\mathrm{mW} / \mathrm{mK}$ (for thermal insulation) 


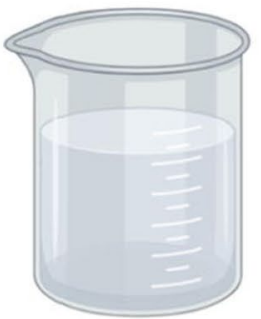

PVA + Fly ash mixture

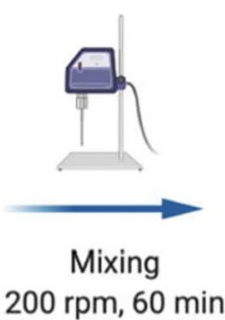

$200 \mathrm{rpm}, 60 \mathrm{~min}$

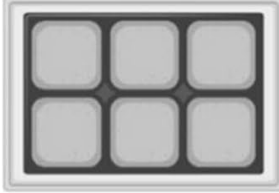

Pouring into a tray

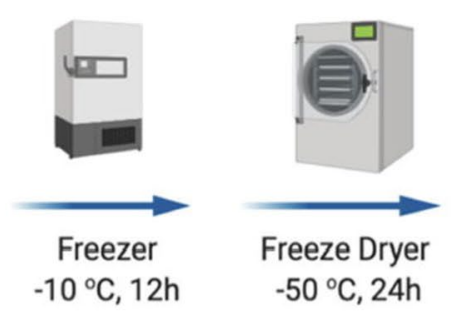

Fly ash aerogel

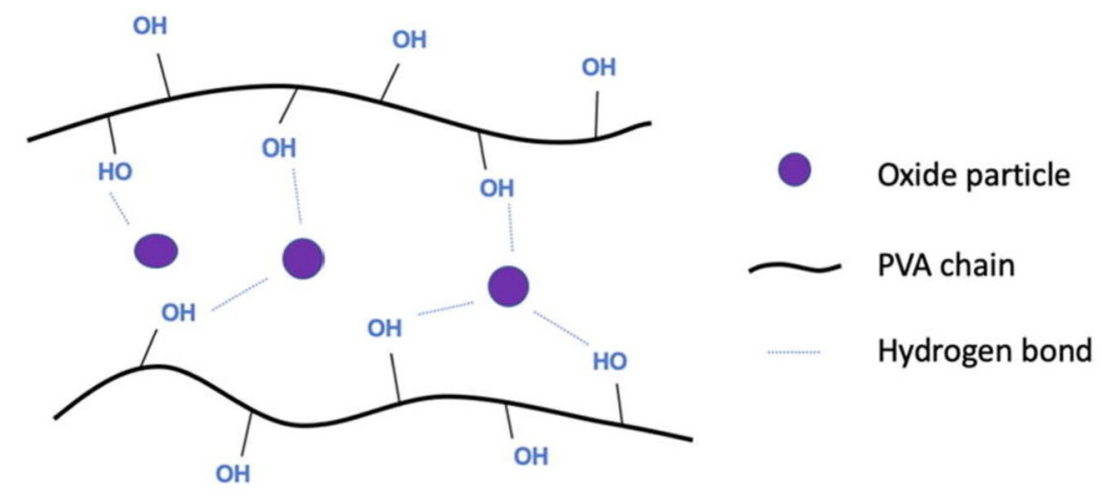

Fig. 8 Fabrication and binding mechanism of aerogels from fly ash. Reprinted from Duong et al. [105], Copyright (2021) with permission from Elsevier

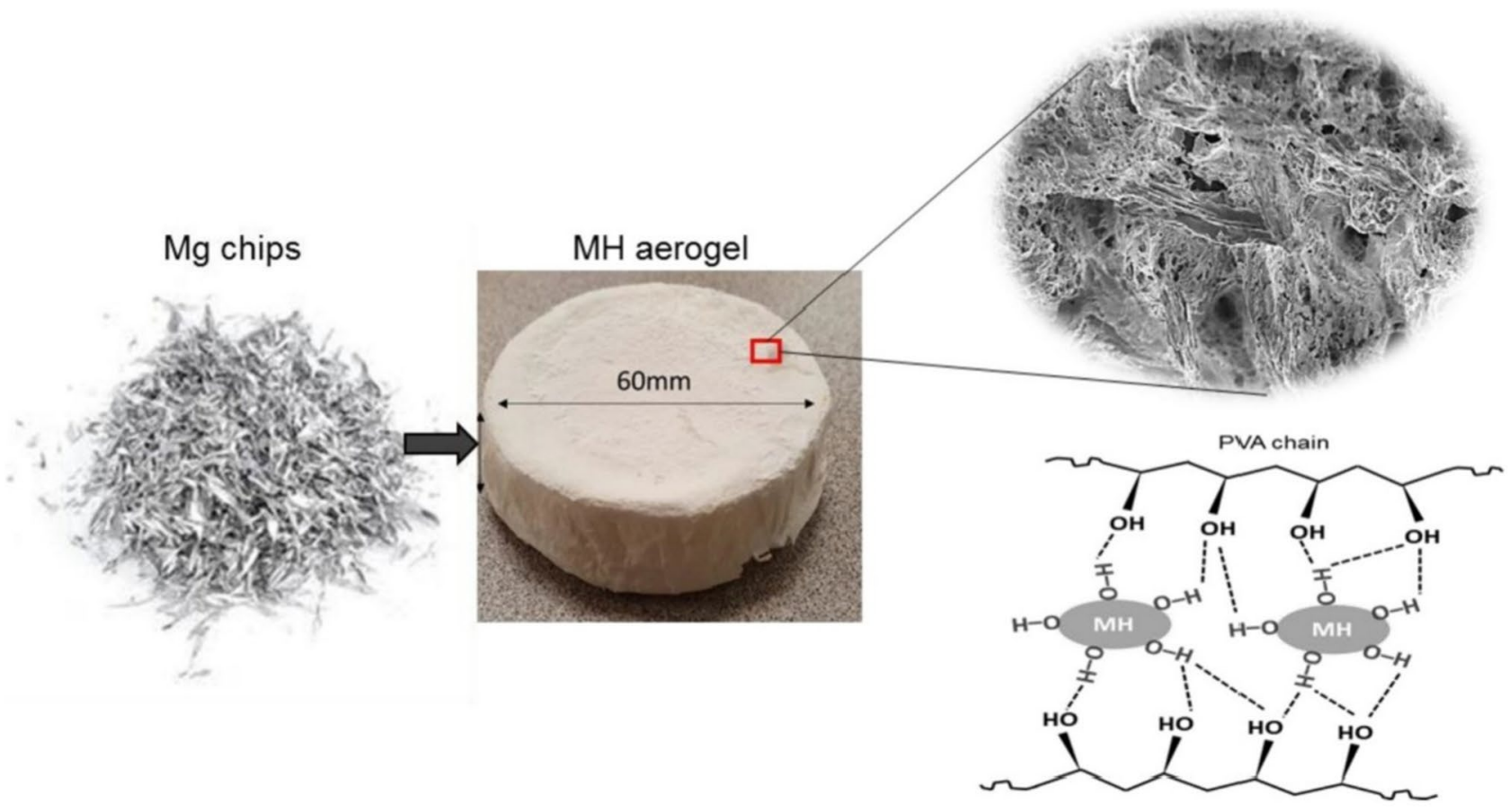

Fig. 9 Appearance, SEM image and crosslinking mechanism of the magnesium hydroxide aerogels from magnesium chips. Reprinted from Yam et al. [114], Copyright (2020) with permission from Elsevier 
into hydrochloric acid $(\mathrm{HCl})$ solution and reprecipitation by $\mathrm{NaOH}$ solution. The $\mathrm{Mg}(\mathrm{OH})_{2}$ particles and the PVA chains are linked by hydrogen bonds. It is proved that the presence of the $\mathrm{Mg}(\mathrm{OH})_{2}$ particles enhances the thermal stability and mechanical properties of the aerogels. The magnesium hydroxide aerogels can withstand up to $800{ }^{\circ} \mathrm{C}$ with approximately $50 \%$ of mass loss. Although $50 \%$ of mass loss is still relatively high, this work suggests a method to fabricate metal-based aerogels for high-temperature resistance. Most of the mass loss can be attributed to the thermal decomposition of the binders. Should binders with higher thermal stability be employed, the overall thermal stability of the aerogels will be significantly improved.

\section{Discussion and Prospective}

Various types of municipal solid, agricultural and industrial wastes have been converted into aerogels with a wide range of applications ranging from heat and sound insulation to energy storage. Remarkably, various multi-functional aerogels have been developed such as coffee grounds aerogels, cotton aerogels and red mud aerogels, which can serve different purposes. The properties of these aerogels, such as low thermal conductivity or high sorption capacity are comparable to the commercial materials, as shown in Fig. 10 [119-126]. By using low-cost, abundant starting materials, they can become sustainable choices for engineering applications such as thermal insulation or oil spill cleaning. For example, producing $1 \mathrm{~m}^{2}$ of rubber aerogel with $1 \mathrm{~cm}$ of
Fig. 10 a Thermal conductivity and $\mathbf{b}$ oil sorption capacity of aerogels from waste and other materials (a)

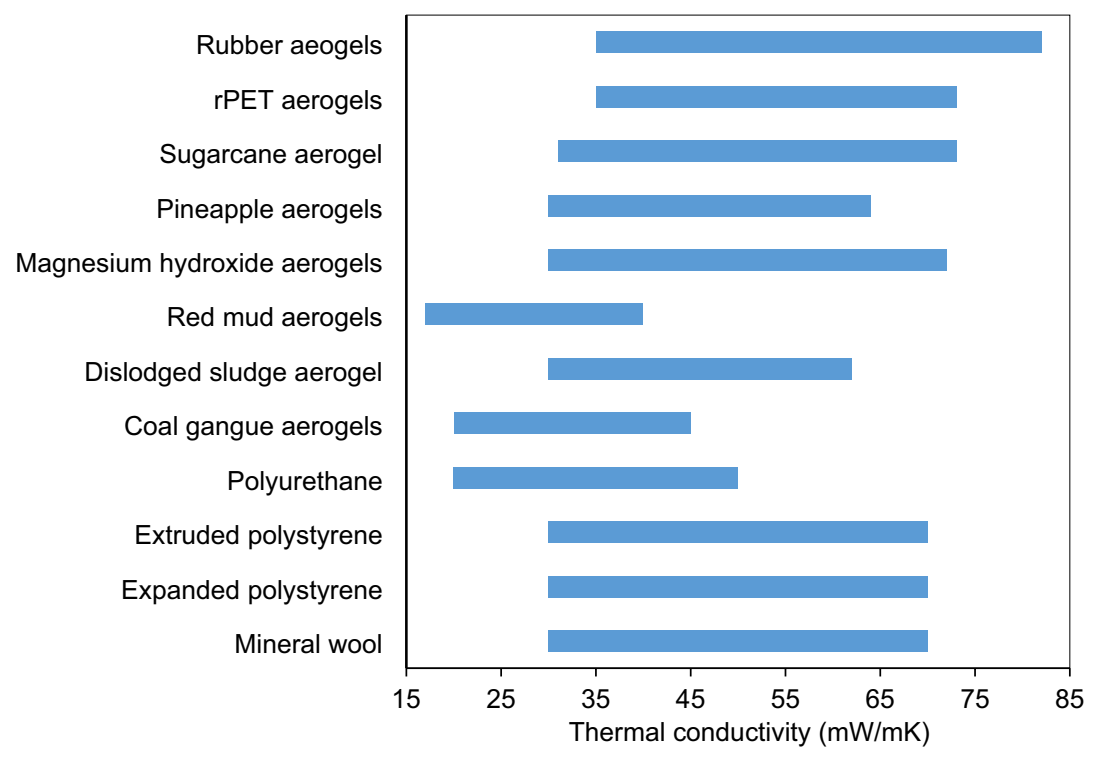

(b)

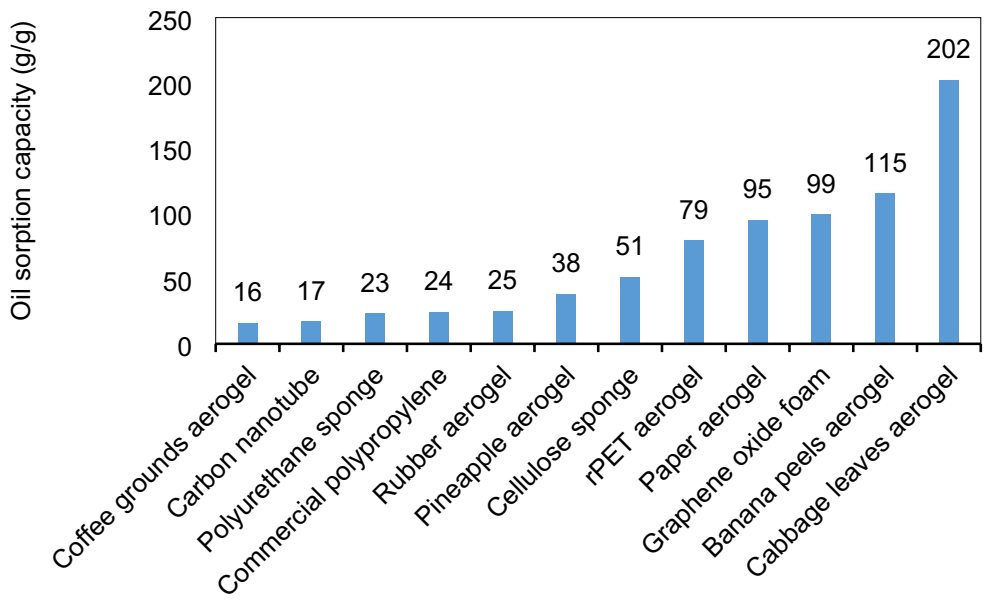


thickness from car tire costs less than 14 USD and takes less than $13 \mathrm{~h}$, making the rubber aerogel competitive with the commercial insulators and sorbents [127].

Besides easing the burden on landfills and incinerators, these works also offer numerous green pathways to mitigate the waste and energy used in the fabrication. For example, Do et al. prepared cellulose aerogels from pineapple fibers without employing any organic solvents [79]. PVA as a biodegradable binder is being commonly consumed to fabricate a stable structure of aerogels from agricultural waste, making the obtained aerogels completely biodegradable. The costeffective freeze-drying method has been frequently applied in numerous works to create a three-dimensional porous network of aerogels. Compared to $\mathrm{scCO}_{2}$ drying, freeze-drying offers various advantages such as less operation time, lower equipment and operation cost, reducing solvent exchange steps in the synthesis procedure, and safer process because of non-requirement of high pressure gas [128]. Especially if environmental impacts are carefully considered, freezedrying is probably the best choice. Moreover, the manufacturing cost of a freeze-dried aerogel is estimated at 42 USD/ $\mathrm{m}^{2}$ at laboratory scale, which is even competitive with the cost of the corresponding $\mathrm{scCO}_{2}$-dried aerogel at industrial scale $\left(21-70 \mathrm{USD} / \mathrm{m}^{2}\right)$ [129]. Besides, conventional batchwise freeze-drying has many disadvantages such as high time and energy consumption, uncontrolled freezing step, inefficient use if loading below maximum capacity, and sample-to-sample variation due to inhomogeneous energy distribution [130, 131]. These drawbacks can be overcome by using continuous freeze-drying. This approach has been investigated in pharmaceuticals production and found to improve the drying efficiency and the product uniformity [132]. Other promising techniques have been studied for the mass and continuous production of aerogels, such as nonwoven [133], continuous solvent exchange [134], fluidized bed drying [135] and continuous $\mathrm{scCO}_{2}$ drying [136].

Waste, especially municipal waste, usually appears as a mixture with complex composition. If waste is not carefully classified from sources, the pretreatment process becomes extremely challenging. Pretreatment of raw materials comes with difficulties such as high cost in chemicals used, timeconsuming process and release of toxic chemicals into the environment. For instance, the removal of ink and glue in newspapers to fabricate cellulose aerogels involves treating the waste newspapers with $\mathrm{NaOH}$ solution and acidified sodium chlorite $\left(\mathrm{NaClO}_{2}\right)$ solution, dispersing the mixture in 1-allyl-3-methylimidazolium chloride ( $\mathrm{AmimCl})$ and rinsing the mixture with ethanol at least six times [37]. Accordingly, alkali solutions, strong oxidants and organic solvents are released, requiring more cost for waste treatment and reducing the sustainability of the recycling process. Therefore, appropriate measures to pretreat the raw materials should be carefully chosen regarding to desired applications to minimize the detrimental effects of the fabrication to the environment and ecosystem.

With the rapidly development of technology, e-waste has attracted a great deal of attention. Technical innovations have shortened the lifespan of electrical devices, leading to the fast rate of e-waste generation. In 2018, 50 million tons of e-waste were generated worldwide. This figure may reach up to 120 million tons by 2050 [137]. Unlike other types of municipal electronic waste, e-waste contains both high value and hazardous materials such as polycyclic aromatic hydrocarbons (PAHs), polychlorinated biphenyls (PCB), heavy metals and rare earth elements [138]. The mentioned work of Yam et al. [114] about metal-based aerogel from metal waste suggests a new way to recycle metals in e-waste into high-value aerogels. If utilized properly, e-waste can become a promising source of precursor for metal-based aerogels in the future.

With multiple extraordinary properties such as ultralightweight, ultralow thermal conductivity, high surface area and high modifiability, aerogels are able to fulfill stringent requirements of military and aerospace [139]. These fields involve situations that requires the insulators or sorbents to withstand extreme conditions, such as fire hazards or in polar regions. Through decades of development, the thermal and mechanical stability of the current aerogels are significantly improved than those of the first silica aerogels. However, to withstand such harsh environments, aerogels are expected to have a higher resistivity to environmental impacts. It is expected that advanced properties such as self-cleaning, self-healing, temperature resistance, and fire retardant will be focused to maintain the performance of aerogels under different working conditions. Inspired by the self-cleaning ability of lotus leaves, Cai et al. [140] prepared functionalized cellulose aerogels with a durable superhydrophobicity and anti-icing properties. The aerogels remain completely clean after pouring coffee, milk, and juice. Moreover, sand powders are easily removed from the aerogel surface by water rushing. This approach will reduce the cleaning and maintenance cost of aerogels insulators for building surfaces or pine line walls. To protect materials from damage and environmental conditions, making self-healable materials is an attractive approach. This class of materials can restore their original structure, properties and functionality after being damaged. There have been some works of self-healable aerogels such as chitosan/itaconic acid aerogels [141] and MXene-graphene composite aerogels [142], suggesting their potential applications in long-life insulators and devices. In addition, aerogels with ultralow or ultrahigh temperature resistivity are developed for both thermal insulation and oil absorption applications. Zhen et al. [143] synthesized the carbon nanofiber aerogels that can maintain high oil absorption capacity up to $139 \mathrm{~g} / \mathrm{g}$ under a wide range of temperature, from liquid nitrogen temperature up to 400 
${ }^{\circ} \mathrm{C}$, suggesting an absorbent for harsh scenarios such as oil spillage in Arctic. It is of worthy notice that conventional sorbents such as polyurethane or polyethylene cannot work above $200{ }^{\circ} \mathrm{C}$ while becoming brittle at low temperature. Feng et al. [144] developed carbon aerogels with a low thermal conductivity of $61 \mathrm{~mW} / \mathrm{mK}$ at $2000{ }^{\circ} \mathrm{C}$ under $0.15 \mathrm{MPa}$ argon, which is promising for space vehicles and military vehicles. Besides, fire-retardant aerogels have been concerned due to their ability to slow down the burning when fire occurs. Fire-retardant phenol-formaldehyde-resin/silica aerogels reported by $\mathrm{Yu}$ et al. [145] can resist up to $1300^{\circ} \mathrm{C}$ flame without disintegration and prevents the temperature on the non-exposed side to increase above $350{ }^{\circ} \mathrm{C}$. Similarly, graphene aerogels prepared by Wang et al. [146] can withstand an alcohol flame even heated to glowing. With a good fire-retardant ability, the applications of these aerogels can be extended to building protective layers or firefighter clothes. There have been few works about investigating these mentioned properties on the aerogels from waste. If these outstanding properties are successfully developed for the aerogels from waste, their values and potentials will be significantly improved.

\section{Conclusions}

The preparation of aerogels from waste has become a novel trend in material science and technology. Waste, with its low cost and abundance, has become a potential precursor for the sustainable syntheses of aerogels, encouraging the conversion of a linear economy to circular economy. Numerous types of municipal solid waste, agricultural waste and industrial waste are upcycled into aerogels with various applications. Those aerogels possess outstanding properties and can compete with commercially available materials in many diverse fields such as thermal insulation and oil spill cleaning. Noticeably, green fabrication methods such as eliminating organic solvents or using biodegradable binders have been more focused by researchers worldwide to create sustainable solutions for waste recycling. However, complex composition of waste, environmental impacts and scalability are current challenges for researchers to overcome. In the future, it is expected that more types of waste can be recycled into aerogels by more eco-friendly methods to create new value from waste and partially combat the increasing waste generation. Moreover, environmental resistivity of the aerogels should be developed to expand their applications in different conditions.

Acknowledgements Authors would like to thank R-265-000-682-114 (MOE Tier 1 FRC) for the financial support.

\section{Declarations}

Conflict of interest There are no conflicts to declare.

\section{References}

1. Wilson, D.G.: Handbook of Solid Waste Management. McGrawHill, New York (1977)

2. Kaza, S., Yao, L.C., Bhada-Tata, P., Van Woerden, F.: What a Waste 2.0: A Global Snapshot of Solid Waste Management to 2050. The World Bank, Washington (2018)

3. Ng, S., Engelsen, C.J.: Construction and demolition wastes. In: Waste and Supplementary Cementitious Materials in Concrete: Characterisation, Properties and Applications, pp. 229-255. Elsevier, Amsterdam (2018)

4. Lewis, H.: Sustainability and the Waste Management Hierarchy-A Discussion Paper. EcoRecycle, Victoria (2003)

5. NEA: Waste management statistics and overall recycling. https:// www.nea.gov.sg/our-services/waste-management/waste-stati stics-and-overall-recycling

6. Yahya, M.A., Al-Qodah, Z., Ngah, C.W.Z.: Agricultural biowaste materials as potential sustainable precursors used for activated carbon production: a review. Renew. Sustain. Energy Rev. 46, 218-235 (2015). https://doi.org/10.1016/j.rser.2015.02.051

7. Akhavan, O., Bijanzad, K., Mirsepah, A.: Synthesis of graphene from natural and industrial carbonaceous wastes. RSC Adv. 4, 20441-20448 (2014). https://doi.org/10.1039/c4ra01550a

8. Mehedi Hasan, M., Nuruzzaman Khan, M., Haque, P., Rahman, M.M.: Novel alginate-di-aldehyde cross-linked gelatin/nanohydroxyapatite bioscaffolds for soft tissue regeneration. Int. J. Biol. Macromol. 117, 1110-1117 (2018). https://doi.org/10. 1016/j.ijbiomac.2018.06.020

9. Shi, G., Shen, Y., Mu, P., Wang, Q., Yang, Y., Ma, S., Li, J.: Effective separation of surfactant-stabilized crude oil-in-water emulsions by using waste brick powder-coated membranes under corrosive conditions. Green Chem. 22, 1345-1352 (2020). https://doi.org/10.1039/c9gc04178h

10. Zhang, L., Xu, Z.: A review of current progress of recycling technologies for metals from waste electrical and electronic equipment. J. Clean. Prod. 127, 19-36 (2016). https://doi.org/ 10.1016/j.jclepro.2016.04.004

11. Ratke, L., Milow, B.: Aerogels for foundry applications. In: Aerogels Handbook. pp. 763-788. Springer, New York (2011)

12. Koebel, M., Rigacci, A., Achard, P.: Aerogel-based thermal superinsulation: an overview. J. Sol-Gel Sci. Technol. 63, 315339 (2012). https://doi.org/10.1007/s10971-012-2792-9

13. BuyAerogel.com: Carbon Aerogel. http://www.buyaerogel.com/ product/carbon-aerogel/

14. High-capacity spherical silica gel, S Series. Chromatography Direct. https://www.chromatographydirect.com/product/4-ghigh-capacity-spherical-silica-gel-15-m-50-700m2-g-ph-6-5-15-300psi-s-series-1460

15. Carlson, G., Lewis, D., McKinley, K., Richardson, J., Tillotson, T.: Aerogel commercialization: technology, markets and costs. J. Non. Cryst. Solids. 186, 372-379 (1995). https://doi.org/10. 1016/0022-3093(95)00069-0

16. Hasan, M.A., Sangashetty, R., Esther, A.C.M., Patil, S.B., Sherikar, B.N., Dey, A.: Prospect of thermal insulation by silica aerogel: a brief review. J. Inst. Eng. (India) Ser. D (2017). https://doi. org/10.1007/s40033-017-0136-1

17. Long, L.-Y., Weng, Y.-X., Wang, Y.-Z.: Cellulose aerogels: synthesis, applications, and prospects. Polymers (Basel) 10, 623 (2018). https://doi.org/10.3390/polym10060623 
18. Hu, L., He, R., Lei, H., Fang, D.: Carbon aerogel for insulation applications: a review. Int. J. Thermophys. (2019). https://doi. org/10.1007/s10765-019-2505-5

19. Mazrouei-Sebdani, Z., Begum, H., Schoenwald, S., Horoshenkov, K.V., Malfait, W.J.: A review on silica aerogel-based materials for acoustic applications. J. Non. Cryst. Solids. 562, 120770 (2021). https://doi.org/10.1016/j.jnoncrysol.2021.120770

20. Wan, W., Zhang, R., Ma, M., Zhou, Y.: Monolithic aerogel photocatalysts: a review. J. Mater. Chem. A 6, 754-775 (2018)

21. Stergar, J., Maver, U.: Review of aerogel-based materials in biomedical applications. J. Sol-Gel Sci. Technol. https://doi.org/10. 1007/s10971-016-3968-5, (2016)

22. Kistler, S.S.: Coherent expanded aerogels and jellies [5]. Nature 127, 741 (1931). https://doi.org/10.1038/127741a0

23. Lide, D.R.: CRC Handbook of Chemistry and Physics. CRC Press, Boca Raton (1992)

24. Akhter, F., Soomro, S.A., Inglezakis, V.J.: Silica aerogels; a review of synthesis, applications and fabrication of hybrid composites. J. Porous Mater. 28, 1387-1400 (2021). https://doi.org/ 10.1007/s10934-021-01091-3

25. Asim, M., Abdan, K., Jawaid, M., Nasir, M., Dashtizadeh, Z., Ishak, M.R., Hoque, M.E., Deng, Y.: A review on pineapple leaves fibre and its composites. Int. J. Polym. Sci. (2015). https:// doi.org/10.1155/2015/950567

26. Udoetok, I.A., Dimmick, R.M., Wilson, L.D., Headley, J.V.: Adsorption properties of cross-linked cellulose-epichlorohydrin polymers in aqueous solution. Carbohydr. Polym. 136, 329-340 (2016). https://doi.org/10.1016/J.CARBPOL.2015.09.032

27. Zhen, L.W., Thai, Q.B., Nguyen, T.X., Le, D.K., Lee, J.K.W., Xiang, Y.Q., Duong, H.M.: Recycled cellulose aerogels from paper waste for a heat insulation design of canteen bottles.Fluids (2019). https://doi.org/10.3390/fluids4030174

28. Nguyen, S.T., Feng, J., Le, N.T., Le, A.T.T., Hoang, N., Tan, V.B.C., Duong, H.M.: Cellulose aerogel from paper waste for crude oil spill cleaning. Ind. Eng. Chem. Res. 52, 18386-18391 (2013). https://doi.org/10.1021/ie4032567

29. Feng, J.D., Nguyen, S.T., Duong, H.M.: Recycled paper cellulose aerogel synthesis and water absorption properties. Adv. Mater. Res. 936, 938-941 (2014). https://doi.org/10.4028/www.scien tific.net/AMR.936.938

30. Feng, J., Nguyen, S.T., Fan, Z., Duong, H.M.: Advanced fabrication and oil absorption properties of super-hydrophobic recycled cellulose aerogels. Chem. Eng. J. 270, 168-175 (2015). https:// doi.org/10.1016/j.cej.2015.02.034

31. Bi, H., Huang, X., Wu, X., Cao, X., Tan, C., Yin, Z., Lu, X., Sun, L., Zhang, H.: Carbon microbelt aerogel prepared by waste paper: an efficient and recyclable sorbent for oils and organic solvents. Small 10, 3544-3550 (2014). https://doi.org/10.1002/ smll.201303413

32. Li, L., Li, B., Sun, H., Zhang, J.: Compressible and conductive carbon aerogels from waste paper with exceptional performance for oil/water separation. J. Mater. Chem. A. 5, 14858-14864 (2017). https://doi.org/10.1039/c7ta03511j

33. Wang, L., Sánchez-Soto, M.: Green bio-based aerogels prepared from recycled cellulose fiber suspensions. RSC Adv. 5, 3138431391 (2015). https://doi.org/10.1039/c5ra02981c

34. Shi, G., Wu, M., Zhong, Q., Mu, P., Li, J.: Superhydrophobic waste cardboard aerogels as effective and reusable oil absorbents. Langmuir (2021). https://doi.org/10.1021/acs.langmuir.1c01216

35. Li, Z., Shao, L., Ruan, Z., Hu, W., Lu, L., Chen, Y.: Converting untreated waste office paper and chitosan into aerogel adsorbent for the removal of heavy metal ions. Carbohydr. Polym. 193, 221-227 (2018). https://doi.org/10.1016/j.carbpol.2018.04.003

36. Srasri, K., Thongroj, M., Chaijiraaree, P., Thiangtham, S., Manuspiya, H., Pisitsak, P., Ummartyotin, S.: Recovery potential of cellulose fiber from newspaper waste: an approach on magnetic cellulose aerogel for dye adsorption material. Int. J. Biol. Macromol. 119, 662-668 (2018). https://doi.org/10.1016/j. ijbiomac.2018.07.123

37. Fan, P., Yuan, Y., Ren, J., Yuan, B., He, Q., Xia, G., Chen, F., Song, R.: Facile and green fabrication of cellulosed based aerogels for lampblack filtration from waste newspaper. Carbohydr. Polym. 162, 108-114 (2017). https://doi.org/10.1016/j.carbpol. 2017.01.015

38. Koh, H.W., Le, D.K., Ng, G.N., Zhang, X., Phan-Thien, N., Kureemun, U., Duong, H.M.: Advanced recycled polyethylene terephthalate aerogels from plastic waste for acoustic and thermal insulation applications. Gels 4, 43 (2018). https://doi.org/10. 3390/gels4020043

39. Le, D.K., Ng, G.N., Koh, H.W., Zhang, X., Thai, Q.B., PhanThien, N., Duong, H.M.: Methyltrimethoxysilane-coated recycled polyethylene terephthalate aerogels for oil spill cleaning applications. Mater. Chem. Phys. 239, 122064 (2020). https:// doi.org/10.1016/j.matchemphys.2019.122064

40. Salomo, S., Nguyen, T.X., Le, D.K., Zhang, X., Phan-Thien, N., Duong, H.M.: Advanced fabrication and properties of hybrid polyethylene tetraphalate fiber-silica aerogels from plastic bottle waste. Colloids Surf. A Physicochem. Eng. Asp. 556, 37-42 (2018). https://doi.org/10.1016/j.colsurfa.2018.08.015

41. Ba Thai, Q., Ee Siang, T., Le Khac, D., Shah, W.A., Phan-Thien, N., Duong, H.M.: Advanced fabrication and multi-properties of rubber aerogels from car tire waste. Colloids Surf. A Physicochem. Eng. Asp. 577, 702-708 (2019). https://doi.org/10.1016/j. colsurfa.2019.06.029

42. Thai, Q.B., Le, D.K., Do, N.H.N., Le, P.K., Phan-Thien, N., Wee, C.Y., Duong, H.M.: Advanced aerogels from waste tire fibers for oil spill-cleaning applications. J. Environ. Chem. Eng. 8, 104016 (2020). https://doi.org/10.1016/j.jece.2020.104016

43. Thai, Q.B., Chong, R.O., Nguyen, P.T.T., Le, D.K., Le, P.K., Phan-Thien, N., Duong, H.M.: Recycling of waste tire fibers into advanced aerogels for thermal insulation and sound absorption applications. J. Environ. Chem. Eng. 8, 104279 (2020). https:// doi.org/10.1016/j.jece.2020.104279

44. Duong, H.M., Lim, Z.K., Nguyen, T.X., Gu, B., Penefather, M.P., Phan-Thien, N.: Compressed hybrid cotton aerogels for stopping liquid leakage. Colloids Surf. A Physicochem. Eng. Asp. 537, 502-507 (2018). https://doi.org/10.1016/j.colsurfa.2017.10.067

45. Han, Y., Zhang, X., Wu, X., Lu, C.: Flame Retardant, Heat insulating cellulose aerogels from waste cotton fabrics by in situ formation of magnesium hydroxide nanoparticles in cellulose gel nanostructures. ACS Sustain. Chem. Eng. 3, 1853-1859 (2015). https://doi.org/10.1021/acssuschemeng.5b00438

46. Chen, H., Wang, X., Li, J., Wang, X.: Cotton derived carbonaceous aerogels for the efficient removal of organic pollutants and heavy metal ions. J. Mater. Chem. A. 3, 6073-6081 (2015). https://doi.org/10.1039/c5ta00299k

47. Asaadi, S., Hummel, M., Hellsten, S., Härkäsalmi, T., Ma, Y., Michud, A., Sixta, H.: Renewable High-Performance Fibers from the Chemical Recycling of Cotton Waste Utilizing an Ionic Liquid. Chemsuschem 9, 3250-3258 (2016). https://doi.org/10.1002/ cssc. 201600680

48. Wang, C., Ding, Y., Yuan, Y., He, X., Wu, S., Hu, S., Zou, M., Zhao, W., Yang, L., Cao, A., Li, Y.: Graphene aerogel composites derived from recycled cigarette filters for electromagnetic wave absorption. J. Mater. Chem. C. 3, 11893-11901 (2015). https:// doi.org/10.1039/c5tc03127c

49. Yang, S., Chen, L., Mu, L., Hao, B., Ma, P.C.: Low cost carbon fiber aerogel derived from bamboo for the adsorption of oils and organic solvents with excellent performances. RSC Adv. 5, 38470-38478 (2015). https://doi.org/10.1039/c5ra03701h

50. Sp, T.S., Nguyen, P.T.T., Do, N.H.N., Le, D.K., Thai, Q.B., Le, P.K., Phan-Thien, N., Duong, H.M.: Advanced fabrication and 
multi-properties of aluminium hydroxide aerogels from aluminium wastes. J. Mater. Cycles Waste Manag. 23, 885-894 (2021). https://doi.org/10.1007/s10163-020-01169-1

51. Garside, M.: Paper Industry-Statistics \& Facts. Chemical and Resources: Pulp and Paper. Statista (2019)

52. Zhou, W., Gong, Z., Zhang, L., Liu, Y., Yan, J., Zhao, M.: Feasibility of lipid production from waste paper by the oleaginous yeast Cryptococcus curvatus. BioResources. 12, 5249-5263 (2017). https://doi.org/10.15376/biores.12.3.5249-5263

53. IUCN: Marine Plastics. IUCN, Gland (2018)

54. d'Ambrières, W.: Plastics recycling worldwide: current overview and desirable changes. Field Actions Science Reports (2019)

55. Promchertchoo, P.: Food delivery services add tonnes of plastic to Thailand's landfills during COVID-19 crisis-CNA, https:// www.channelnewsasia.com/news/asia/food-delivery-increasesthailand-plastic-waste-during-covid-19-12711692

56. Zhu, L., Wang, Y., Wang, Y., You, L., Shen, X., Li, S.: An environmentally friendly carbon aerogels derived from waste pomelo peels for the removal of organic pollutants/oils. Microporous Mesoporous Mater. 241, 285-292 (2017). https://doi.org/10. 1016/j.micromeso.2016.12.033

57. OECD/FA: OECD-FAO Agricultural Outlook 2019-2028. OECD Agriculture Statistics (Database) (2019). https://doi.org/ 10.1787/agr-outl-data-en

58. Madsen, B., Gamstedt, E.K.: Wood versus plant fibers: similarities and differences in composite applications. Adv. Mater. Sci. Eng. (2013). https://doi.org/10.1155/2013/564346

59. Loh, J.W., Goh, X.Y., Nguyen, P.T.T., Thai, Q.B., Ong, Z.Y., Duong, H.M.: Advanced aerogels from wool waste fibers for oil spill cleaning applications. J. Polym. Environ. (2021). https://doi. org/10.1007/s10924-021-02234-y

60. Obi, F., Ugwuishiwu, B., Nwakaire, J.: Agricultural waste concept, generation, utilization and management. Niger. J. Technol. 35, 957 (2016). https://doi.org/10.4314/njt.v35i4.34

61. Sundarraj, A.A., Ranganathan, T.V.: A review on cellulose and its utilization from agro-industrial waste. Drug Invent. Today. 10, 89-94 (2018)

62. Ilyas, R.A., Sapuan, S.M., Ibrahim, R., Atikah, M.S.N., Atiqah, A., Ansari, M.N.M., Norrrahim, M.N.F.: Production, processes and modification of nanocrystalline cellulose from agro-waste: a review. In: Nanocrystalline Materials. IntechOpen, London (2020)

63. Permatasari, N., Sucahya, T.N., Dani Nandiyanto, A.B.: Review: Agricultural wastes as a source of silica material. Indones. J. Sci. Technol. 1, 82 (2016). https://doi.org/10.17509/ijost.v1i1.2216

64. Ben-Othman, S., Jõudu, I., Bhat, R.: Bioactives from agri-food wastes: present insights and future challenges. Molecules (2020). https://doi.org/10.3390/molecules25030510

65. Singh, B.: Rice husk ash. In: Waste and Supplementary Cementitious Materials in Concrete: Characterisation, Properties and Applications, pp. 417-460. Elsevier, Amsterdam (2018)

66. Phonphuak, N., Chindaprasirt, P.: Types of waste, properties, and durability of pore-forming waste-based fired masonry bricks. In: Eco-efficient Masonry Bricks and Blocks: Design, Properties and Durability, pp. 103-127. Elsevier, Amsterdam (2015)

67. Green Earth Aerogel: http://www.green-earth-aerogel.com/

68. Gurav, J.L., Jung, I.K., Park, H.H., Kang, E.S., Nadargi, D.Y.: Silica aerogel: Synthesis and applications. J. Nanomater. (2010). https://doi.org/10.1155/2010/409310

69. Şahin, İ, Özbakır, Y., Inönü, Z., Ulker, Z., Erkey, C.: Kinetics of supercritical drying of gels. Gels (2018). https://doi.org/10.3390/ gels4010003

70. Li, T., Wang, T.: Preparation of silica aerogel from rice hull ash by drying at atmospheric pressure. Mater. Chem. Phys. 112, 398-401 (2008). https://doi.org/10.1016/j.matchemphys.2008. 05.066
71. Tadjarodi, A., Haghverdi, M., Mohammadi, V.: Preparation and characterization of nano-porous silica aerogel from rice husk ash by drying at atmospheric pressure. Mater. Res. Bull. 47, 2584-2589 (2012). https://doi.org/10.1016/j.materresbull.2012. 04.143

72. Nayak, J.P., Bera, J.: Preparation of silica aerogel by ambient pressure drying process using rice husk ash as raw material. Trans. Indian Ceram. Soc. 68, 91-94 (2009). https://doi.org/10. 1080/0371750X.2009.11082163

73. Cui, S., Yu, S.W., Lin, B.L., Shen, X.D., Gu, D.: Preparation of $\mathrm{SiO}_{2}$ aerogel from rice husk ash. RSC Adv. 5, 65818-65826 (2015). https://doi.org/10.1039/c5ra08886k

74. Tang, Q., Wang, T.: Preparation of silica aerogel from rice hull ash by supercritical carbon dioxide drying. J. Supercrit. Fluids 35, 91-94 (2005). https://doi.org/10.1016/j.supflu.2004.12.003

75. Abdul Halim, Z.A., Mat Yajid, M.A., Hamdan, H.: Synthesis and characterization of rice husk ash derived-silica aerogel beads prepared by ambient pressure drying. Key Eng. Mater. 694, 106-110 (2016). https://doi.org/10.4028/www.scientific.net/ KEM.694.106

76. Kumar Rajanna, S., Vinjamur, M., Mukhopadhyay, M.: Mechanism for formation of hollow and granular silica aerogel microspheres from rice husk ash for drug delivery. J. Non. Cryst. Solids 429, 226-231 (2015). https://doi.org/10.1016/j.jnoncrysol. 2015.09.015

77. Babbar, N., Oberoi, H.S.: Enzymes in value-addition of agricultural and agro-industrial residues. In: Enzymes in Value-Addition of Wastes, pp. 29-50. Nova Science Publishers, New York (2014)

78. Cheok, C.Y., Adzahan, N.M., Rahman, R.A., Abedin, N.H.Z., Hussain, N., Sulaiman, R., Chong, G.H.: Current trends of tropical fruit waste utilization. Crit. Rev. Food Sci. Nutr. 58, 335-361 (2017). https://doi.org/10.1080/10408398.2016.1176009

79. Do, N.H.N., Luu, T.P., Thai, Q.B., Le, D.K., Chau, N.D.Q., Nguyen, S.T., Le, P.K., Phan-Thien, N., Duong, H.M.: Advanced fabrication and application of pineapple aerogels from agricultural waste. Mater. Technol. 35, 807-814 (2020). https://doi.org/ $10.1080 / 10667857.2019 .1688537$

80. Do, N.H.N., Luu, T.P., Thai, Q.B., Le, D.K., Chau, N.D.Q., Nguyen, S.T., Le, P.K., Phan-Thien, N., Duong, H.M.: Heat and sound insulation applications of pineapple aerogels from pineapple waste. Mater. Chem. Phys. 242, 122267 (2020). https://doi. org/10.1016/j.matchemphys.2019.122267

81. Lim, Z.E., Thai, Q.B., Le, D.K., Luu, T.P., Nguyen, P.T.T., Do, N.H.N., Le, P.K., Phan-Thien, N., Goh, X.Y., Duong, H.M.: Functionalized pineapple aerogels for ethylene gas adsorption and nickel (II) ion removal applications. J. Environ. Chem. Eng. 8, 104524 (2020). https://doi.org/10.1016/j.jece.2020.104524

82. Thai, Q.B., Nguyen, S.T., Ho, D.K., Tran, TDu., Huynh, D.M., Do, N.H.N., Luu, T.P., Le, P.K., Le, D.K., Phan-Thien, N., Duong, H.M.: Cellulose-based aerogels from sugarcane bagasse for oil spill-cleaning and heat insulation applications. Carbohydr. Polym. 228, 115365 (2020). https://doi.org/10.1016/j.carbpol. 2019.115365

83. Wan, C., Lu, Y., Jiao, Y., Jin, C., Sun, Q., Li, J.: Ultralight and hydrophobic nanofibrillated cellulose aerogels from coconut shell with ultrastrong adsorption properties. J. Appl. Polym. Sci. (2015). https://doi.org/10.1002/app.42037

84. Wang, Y., Zhu, L., Zhu, F., You, L., Shen, X., Li, S.: Removal of organic solvents/oils using carbon aerogels derived from waste durian shell. J. Taiwan Inst. Chem. Eng. 78, 351-358 (2017). https://doi.org/10.1016/j.jtice.2017.06.037

85. Hao, P., Zhao, Z., Tian, J., Li, H., Sang, Y., Yu, G., Cai, H., Liu, H., Wong, C.P., Umar, A.: Hierarchical porous carbon aerogel derived from bagasse for high performance supercapacitor electrode. Nanoscale 6, 12120-12129 (2014). https://doi.org/10. 1039/c4nr03574g 
86. Cai, T., Wang, H., Jin, C., Sun, Q., Nie, Y.: Fabrication of nitrogen-doped porous electrically conductive carbon aerogel from waste cabbage for supercapacitors and oil/water separation. J. Mater. Sci. Mater. Electron. 29, 4334-4344 (2018). https://doi. org/10.1007/s10854-017-8381-5

87. Yue, X., Zhang, T., Yang, D., Qiu, F., Li, Z.: Hybrid aerogels derived from banana peel and waste paper for efficient oil absorption and emulsion separation. J. Clean. Prod. 199, 411-419 (2018). https://doi.org/10.1016/j.jclepro.2018.07.181

88. Zhu, L., Jiang, H., Ran, W., You, L., Yao, S., Shen, X., Tu, F.: Turning biomass waste to a valuable nitrogen and boron dualdoped carbon aerogel for high performance lithium-sulfur batteries. Appl. Surf. Sci. 489, 154-164 (2019). https://doi.org/10. 1016/j.apsusc.2019.05.333

89. Nazriati, N., Setyawan, H., Affandi, S., Yuwana, M., Winardi, S.: Using bagasse ash as a silica source when preparing silica aerogels via ambient pressure drying. J. Non. Cryst. Solids. 400, 6-11 (2014). https://doi.org/10.1016/j.jnoncrysol.2014.04.027

90. Zhang, X., Kwek, L.P., Le, D.K., Tan, M.S., Duong, H.M.: Fabrication and properties of hybrid coffee-cellulose aerogels from spent coffee grounds. Polymers (Basel) 11, 1942 (2019). https:// doi.org/10.3390/polym11121942

91. Lee, K., Shabnam, L., Faisal, S.N., Hoang, V.C., Gomes, V.G.: Aerogel from fruit biowaste produces ultracapacitors with high energy density and stability. J. Energy Storage. 27, 101152 (2020). https://doi.org/10.1016/j.est.2019.101152

92. Wu, X.L., Wen, T., Guo, H.L., Yang, S., Wang, X., Xu, A.W.: Biomass-derived sponge-like carbonaceous hydrogels and aerogels for supercapacitors. ACS Nano 7, 3589-3597 (2013). https:// doi.org/10.1021/nn400566d

93. Wang, W., Fang, Y., Ni, X., Wu, K., Wang, Y., Jiang, F., Riffat, S.B.: Fabrication and characterization of a novel konjac glucomannan-based air filtration aerogels strengthened by wheat straw and okara. Carbohydr. Polym. (2019). https://doi.org/10. 1016/j.carbpol.2019.115129

94. Li, N., Yue, Q., Gao, B., Xu, X., Su, R., yu, B.: One-step synthesis of peanut hull/graphene aerogel for highly efficient oil-water separation. J. Clean. Prod. 207, 764-771 (2019). https://doi.org/ 10.1016/j.jclepro.2018.10.038

95. Luu, T.P., Do, N.H.N., Chau, N.D.Q., Lai, D.Q., Nguyen, S.T., Le, D.K., Thai, Q.B., Le, P.T.K., Duong, H.M.: Morphology control and advanced properties of bio-aerogels from pineapple leaf waste. Chem. Eng. Trans. 78, 433-438 (2020). https://doi.org/ 10.3303/CET2078073

96. Payá, J., Monzó, J., Borrachero, M.V., Tashima, M.M.: Reuse of aluminosilicate industrial waste materials in the production of alkali-activated concrete binders. In: Handbook of Alkali-Activated Cements, Mortars and Concretes, pp. 487-518. Elsevier, Amsterdam (2015)

97. Rungchet, A., Chindaprasirt, P., Wansom, S., Pimraksa, K.: Hydrothermal synthesis of calcium sulfoaluminate-belite cement from industrial waste materials. J. Clean. Prod. 115, 273-283 (2016). https://doi.org/10.1016/j.jclepro.2015.12.068

98. Ahmed, M.J.K., Ahmaruzzaman, M.: A review on potential usage of industrial waste materials for binding heavy metal ions from aqueous solutions. J. Water Process Eng. 10, 39-47 (2016). https://doi.org/10.1016/j.jwpe.2016.01.014

99. Duan, H., Huang, Q., Wang, Q., Zhou, B., Li, J.: Hazardous waste generation and management in China: a review. J. Hazard. Mater. 158, 221-227 (2008). https://doi.org/10.1016/j.jhazmat.2008.01. 106

100. Wu, X., Fan, M., Mclaughlin, J.F., Shen, X., Tan, G.: A novel low-cost method of silica aerogel fabrication using fly ash and trona ore with ambient pressure drying technique. Powder Technol. 323, 310-322 (2018). https://doi.org/10.1016/j.powtec.2017. 10.022
101. Shi, F., Liu, J.X., Song, K., Wang, Z.Y.: Cost-effective synthesis of silica aerogels from fly ash via ambient pressure drying. J. Non. Cryst. Solids. 356, 2241-2246 (2010). https://doi.org/ 10.1016/j.jnoncrysol.2010.08.005

102. Cheng, Y., Xia, M., Luo, F., Li, N., Guo, C., Wei, C.: Effect of surface modification on physical properties of silica aerogels derived from fly ash acid sludge. Colloids Surf. A Physicochem. Eng. Asp. 490, 200-206 (2016). https://doi.org/10. 1016/j.colsurfa.2015.11.055

103. Cheng, Y., Li, N., Wei, C.: Effect of the TMCS/hydrogel volume ratio on physical properties of silica aerogels based on fly ash acid sludge. J. Sol-Gel Sci. Technol. 78, 279-284 (2016). https://doi.org/10.1007/s10971-015-3954-3

104. Wang, H.L., Qi, H.P., Wei, X.N., Liu, X.Y., Jiang, W.F.: Photocatalytic activity of $\mathrm{TiO} 2$ supported $\mathrm{SiO}_{2}-\mathrm{Al}_{2} \mathrm{O}_{3}$ aerogels prepared from industrial fly ash. Chin. J. Catal. 37, 2025-2033 (2016). https://doi.org/10.1016/S1872-2067(16)62546-9

105. Duong, H.M., Ling, N.R.B., Thai, Q.B., Le, D.K., Nguyen, P.T.T., Goh, X.Y., Phan-Thien, N.: A novel aerogel from thermal power plant waste for thermal and acoustic insulation applications. Waste Manag. 124, 1-7 (2021). https://doi.org/ 10.1016/j.wasman.2021.01.031

106. Do, N.H.N., Tran, H.G., Doan, H.L.X., Pham, N.Q., Le, K.A., Le, P.K.: Advanced fabrication of lightweight aerogels from fly ash for thermal insulation. Sci. Technol. Dev. J. Eng. Technol. (2021). https://doi.org/10.32508/stdjet.v3i4.786

107. Zhu, P., Zheng, M., Zhao, S., Wu, J., Xu, H.: Synthesis and thermal insulation performance of silica aerogel from recycled coal gangue by means of ambient pressure drying. J. Wuhan Univ. Technol. Mater. Sci. Ed. 30, 908-913 (2015). https://doi. org/10.1007/s11595-015-1248-9

108. Zhu, P., Zheng, M., Zhao, S., Wu, J., Xu, H.: A novel environmental route to ambient pressure dried thermal insulating silica aerogel via recycled coal gangue. Adv. Mater. Sci. Eng. 2016, 9831515 (2016). https://doi.org/10.1155/2016/9831515

109. Du, M.H., Wei, Q., Nie, Z.R., Cui, S.P., Liu, S.W., Li, Q.Y.: A rapid and low solvent/silylation agent-consumed synthesis, pore structure and property of silica aerogels from dislodged sludge. J. Sol-Gel Sci. Technol. 81, 427-435 (2017). https:// doi.org/10.1007/s10971-016-4206-X

110. Karamahmut Mermer, N., Sari Yilmaz, M., Dere Ozdemir, O., Piskin, M.B.: The synthesis of silica-based aerogel from gold mine waste for thermal insulation. J. Therm. Anal. Calorim. 129, 1807-1812 (2017). https://doi.org/10.1007/ s10973-017-6371-8

111. de Oliveira, P.B., Godinho, M., Zattera, A.J.: Oils sorption on hydrophobic nanocellulose aerogel obtained from the wood furniture industry waste. Cellulose 25, 3105-3119 (2018). https:// doi.org/10.1007/s10570-018-1781-8

112. Zhu, G., Xu, H., Dufresne, A., Lin, N.: High-adsorption, selfextinguishing, thermal, and acoustic-resistance aerogels based on organic and inorganic waste valorization from cellulose nanocrystals and red Mud. ACS Sustain. Chem. Eng. 6, 71687180 (2018). https://doi.org/10.1021/acssuschemeng.8b01244

113. Mekonnen, B.T., Ragothaman, M., Kalirajan, C., Palanisamy, T.: Conducting collagen-polypyrrole hybrid aerogels made from animal skin waste. RSC Adv. 6, 63071-63077 (2016). https://doi. org/10.1039/c6ra08876g

114. Yam, B.J.Y., Le, D.K., Do, N.H., Nguyen, P.T.T., Thai, Q.B., Phan-Thien, N., Duong, H.M.: Recycling of magnesium waste into magnesium hydroxide aerogels. J. Environ. Chem. Eng. 8, 104101 (2020). https://doi.org/10.1016/j.jece.2020.104101

115. Guo, Y., Li, Y., Cheng, F., Wang, M., Wang, X.: Role of additives in improved thermal activation of coal fly ash for alumina extraction. Fuel Process. Technol. 110, 114-121 (2013). https:// doi.org/10.1016/j.fuproc.2012.12.003 
116. Do, N.H.N., Le, T.M., Tran, H.Q., Pham, N.Q., Le, K.A., Nguyen, P.T.T., Duong, H.M., Le, T.A., Le, P.K.: Green recycling of fly ash into heat and sound insulation composite aerogels reinforced by recycled polyethylene terephthalate fibers. J. Clean. Prod. 322, 129138 (2021). https://doi.org/10.1016/j.jclepro.2021.129138

117. Rajamani, S., Puig, R.: Recent developments in cleaner production and environment protection in world leather sector. In: 31 st IULTCS Congress (2011)

118. Masilamani, D., Madhan, B., Shanmugam, G., Palanivel, S., Narayan, B.: Extraction of collagen from raw trimming wastes of tannery: A waste to wealth approach. J. Clean. Prod. 113, 338-344 (2016). https://doi.org/10.1016/j.jclepro.2015.11.087

119. Sun-Central Company, L.: Polypropylene micro fiber oil adsorbent, https://www.gfsfilter.com/pdf/oil-adsorbents.pdf

120. Li, B., Liu, X., Zhang, X., Zou, J., Chai, W., Lou, Y.: Rapid adsorption for oil using superhydrophobic and superoleophilic polyurethane sponge. J. Chem. Technol. Biotechnol. 90, 2106-2112 (2015). https://doi.org/10.1002/jctb.4646

121. Kayvani Fard, A., Mckay, G., Manawi, Y., Malaibari, Z., Hussien, M.A.: Outstanding adsorption performance of high aspect ratio and super-hydrophobic carbon nanotubes for oil removal. Chemosphere 164, 142-155 (2016). https://doi.org/10.1016/j.chemosphere.2016. 08.099

122. Lu, Y., Wang, Y., Liu, L., Yuan, W.: Environmental-friendly and magnetic/silanized ethyl cellulose sponges as effective and recyclable oil-absorption materials. Carbohydr. Polym. 173, 422-430 (2017). https://doi.org/10.1016/j.carbpol.2017.06.009

123. He, Y., Liu, Y., Wu, T., Ma, J., Wang, X., Gong, Q., Kong, W., Xing, F., Liu, Y., Gao, J.: An environmentally friendly method for the fabrication of reduced graphene oxide foam with a super oil absorption capacity. J. Hazard. Mater. 260, 796-805 (2013). https:// doi.org/10.1016/j.jhazmat.2013.06.042

124. Jelle, B.P., Tilset, B.G., Jahren, S., Gao, T., Gustavsen, A.: Vacuum and nanotechnologies for the thermal insulation materials of beyond tomorrow-from concept to experimental investigations. In: Proceedings of the 10th International Vacuum Insulation Symposium (IVIS X), pp. 171-178 (2011)

125. Aditya, L., Mahlia, T.M.I., Rismanchi, B., Ng, H.M., Hasan, M.H., Metselaar, H.S.C., Muraza, O., Aditiya, H.B.: A review on insulation materials for energy conservation in buildings. Renew. Sustain. Energy Rev. 73, 1352-1365 (2017). https://doi.org/10.1016/j.rser. 2017.02.034

126. Briga-Sá, A., Nascimento, D., Teixeira, N., Pinto, J., Caldeira, F., Varum, H., Paiva, A.: Textile waste as an alternative thermal insulation building material solution. Constr. Build. Mater. 38, 155-160 (2013). https://doi.org/10.1016/j.conbuildmat.2012.08.037

127. The world's first aerogels made from scrap rubber tyres. https://news.nus.edu.sg/the-worlds-first-aerog els-made-from-scrap-rubber-tyres/

128. Barrios, E., Fox, D., Li Sip, Y.Y., Catarata, R., Calderon, J.E., Azim, N., Afrin, S., Zhang, Z., Zhai, L.: Nanomaterials in advanced, high-performance aerogel composites: a review. Polymers (Basel). 11, 726 (2019). https://doi.org/10.3390/polym11040 726

129. Członka, S., Bertino, M.F., Kośny, J., Shukla, N.: Freeze-drying method as a new approach to the synthesis of polyurea aerogels from isocyanate and water. J. Sol-Gel Sci. Technol. 87, 685-695 (2018). https://doi.org/10.1007/s10971-018-4769-9

130. Van Bockstal, P.J., De Meyer, L., Corver, J., Vervaet, C., De Beer, T.: Noncontact infrared-mediated heat transfer during continuous freeze-drying of unit doses. J. Pharm. Sci. 106, 71-82 (2017). https://doi.org/10.1016/j.xphs.2016.05.003

131. Van Bockstal, P.J., Mortier, S.T.F.C., De Meyer, L., Corver, J., Vervaet, C., Nopens, I., De Beer, T.: Mechanistic modelling of infrared mediated energy transfer during the primary drying step of a continuous freeze-drying process. Eur. J. Pharm. Biopharm. 114, 11-21 (2017). https://doi.org/10.1016/j.ejpb.2017.01.001
132. De Meyer, L., Lammens, J., Vanbillemont, B., Van Bockstal, P.J., Corver, J., Vervaet, C., Friess, W., De Beer, T.: Dual chamber cartridges in a continuous pharmaceutical freeze-drying concept: determination of the optimal dynamic infrared heater temperature during primary drying. Int. J. Pharm. 570, 118631 (2019). https:// doi.org/10.1016/j.jpharm.2019.118631

133. Technical-scale production of aerogel nonwovens. International Fiber Journal. https://fiberjournal.com/technical-scale-productionof-aerogel-nonwovens/

134. Lázár, I., Fábián, I.: A continuous extraction and pumpless supercritical $\mathrm{CO}_{2}$ drying system for laboratory-scale aerogel production. Gels 2, 26 (2016). https://doi.org/10.3390/gels2040026

135. Bhagat, S.D., Park, K.T., Kim, Y.H., Kim, J.S., Han, J.H.: A continuous production process for silica aerogel powders based on sodium silicate by fluidized bed drying of wet-gel slurry. Solid State Sci. 10, 1113-1116 (2008). https://doi.org/10.1016/j.solid statesciences.2007.11.016

136. Mißfeldt, F., Gurikov, P., Lölsberg, W., Weinrich, D., Lied, F., Fricke, M., Smirnova, I.: Continuous supercritical drying of aerogel particles: proof of concept. Ind. Eng. Chem. Res. 59, 11284-11295 (2020). https://doi.org/10.1021/acs.iecr.0c01356

137. Wang, T.: Global E-Waste-Statistics \& Facts. Statista (2018)

138. Robinson, B.H.: E-waste: an assessment of global production and environmental impacts. Sci. Total Environ. 408, 183-191 (2009). https://doi.org/10.1016/j.scitotenv.2009.09.044

139. Hebalkar, N., Kollipara, K.S., Ananthan, Y., Sudha, M.K.: Nanoporous aerogels for defense and aerospace applications. In: Handbook of Advanced Ceramics and Composites. pp. 121-163. Springer, Cham (2020)

140. Cai, C., Wei, Z., Huang, Y., Ding, C., Wang, P., Song, J., Deng, L., $\mathrm{Fu}$, Y., Zhong, W.H.: Ultralight programmable bioinspired aerogels with an integrated multifunctional surface for self-cleaning, oil absorption, and thermal insulation via coassembly. ACS Appl. Mater. Interfaces. (2020). https://doi.org/10.1021/acsami.0c00308

141. Yang, J., Yi, L., Fang, X., Song, Y., Zhao, L., Wu, J., Wu, H.: Self-healing and recyclable biomass aerogel formed by electrostatic interaction. Chem. Eng. J. 371, 213-221 (2019). https://doi.org/10. 1016/j.cej.2019.04.057

142. Yue, Y., Liu, N., Ma, Y., Wang, S., Liu, W., Luo, C., Zhang, H., Cheng, F., Rao, J., Hu, X., Su, J., Gao, Y.: Highly self-healable 3D microsupercapacitor with MXene-graphene composite aerogel. ACS Nano 12, 4224-4232 (2018). https://doi.org/10.1021/acsnano. $7 \mathrm{~b} 07528$

143. Wu, Z.Y., Li, C., Liang, H.W., Zhang, Y.N., Wang, X., Chen, J.F., Yu, S.H.: Carbon nanofiber aerogels for emergent cleanup of oil spillage and chemical leakage under harsh conditions. Sci. Rep. 3, 1-6 (2014). https://doi.org/10.1038/srep04079

144. Feng, J., Feng, J., Jiang, Y., Zhang, C.: Ultralow density carbon aerogels with low thermal conductivity up to $2000{ }^{\circ} \mathrm{C}$. Mater. Lett. 65, 3454-3456 (2011). https://doi.org/10.1016/j.matlet.2011.07. 114

145. Yu, Z.L., Yang, N., Apostolopoulou-Kalkavoura, V., Qin, B., Ma, Z.Y., Xing, W.Y., Qiao, C., Bergström, L., Antonietti, M., Yu, S.H.: Fire-retardant and thermally insulating phenolic-silica aerogels. Angew. Chem. Int. Ed. 57, 4538-4542 (2018). https://doi.org/10. 1002/anie.201711717

146. Wang, Z., Wei, R., Gu, J., Liu, H., Liu, C., Luo, C., Kong, J., Shao, Q., Wang, N., Guo, Z., Liu, X.: Ultralight, highly compressible and fire-retardant graphene aerogel with self-adjustable electromagnetic wave absorption. Carbon N. Y. 139, 1126-1135 (2018). https://doi. org/10.1016/j.carbon.2018.08.014

Publisher's Note Springer Nature remains neutral with regard to jurisdictional claims in published maps and institutional affiliations. 


\section{Authors and Affiliations}

Phuc T. T. Nguyen ${ }^{1} \cdot$ Nga H. N. Do ${ }^{4,5} \cdot$ Xue Yang Goh ${ }^{1}$. Chong Jin Goh ${ }^{1} \cdot$ Ren Hong Ong ${ }^{1}$ Phung K. Le ${ }^{4,5}$. Nhan Phan-Thien ${ }^{1} \cdot$ Hai M. Duong ${ }^{1,2,3}$

1 Department of Mechanical Engineering, National University of Singapore, Singapore, Singapore

2 University of Cuu Long (UCL), Vinh Long, Vinh Long Province, Vietnam

3 Department of Chemical Engineering, Stanford University, Stanford, USA
4 Refinery and Petrochemical Technology Research Centre, Ho Chi Minh City University of Technology (HCMUT), 268 Ly Thuong Kiet Street, District 10, Ho Chi Minh City, Vietnam

5 Vietnam National University Ho Chi Minh City, Linh Trung Ward, Thu Duc District, Ho Chi Minh City, Vietnam 